\title{
LA GANADERÍA EN ELCHE MEDIEVAL
}

\author{
José Hinojosa Montalvo \\ Universidad DE Alicante
}

\begin{abstract}
Resumen: En el presente artículo se realiza un estudio minucioso sobre el fenómeno ganadero en la villa de Elche durante los siglos bajomedievales atendiendo a diversos criterios de análisis como la actividad de los pastores, la funciones de las zonas de pasto, las especies, la trashumancia, la diversidad de conflictos institucionales y sociales que giraban entorno a la cabaña ganadera y la importancia de los productos ganaderos que se derivan al mercado, así como el papel de la comunidad mudéjar en esta actividad económica.
\end{abstract}

Palabras clave: Elche, ganado, pastores, trashumancia, conflictos.

Abstract: In this article it is carried out a detailed study on the cattle farming in the town of Elche during the late middle age centuries, according to several analysis criteria as the activity of the shepherds, the functions of the pasture, the species, the transhumance, the diversity of institutional and social conflicts that revolved around the livestock and the importance of the cattle products that were led to the market, as well as the part of the mudéjar community in this economic activity.

Keywords: Elche, livestock, shepherds, transhumance, conflicts.

\section{INTRODUCCIÓN}

El binomio agricultura-ganadería fue consustancial en la Edad Media en la economía del reino de Valencia, igual que en el resto de Occidente. Nada hay, por tanto, que nos diferencie, en líneas generales, del resto de países, ahora bien, dentro del propio reino es evidente que esta dedicación ganadera no tenía la misma importancia en todas las comarcas y localidades, pudiendo apreciarse en algunas de ellas una orientación preferente hacia la economía ganadera y el 
aprovechamiento de la lana, como fue el caso de las comarcas septentrionales de Els Ports de Morella y el Maestrat, hasta el punto de que autores como F. Melis hablaron de un área de la lana, a la hora de clasificar los espacios económicos del reino ${ }^{1}$.

En cambio, en las tierras meridionales del reino, el panorama era diferente, sin que pueda hablarse de comarcas ganaderas, aunque sí de un aprovechamiento ganadero, más o menos intensivo, a partir de una serie de factores, como eran la existencia de amplias zonas del territorio sin cultivar, con una climatología favorable en invierno, poco pobladas, lo que las hacían aptas para su uso como pastos para los ganados locales y trashumantes, pero donde la ganadería nunca fue el motor de la economía, aunque sí una fuente de riqueza, complementaria o en sí misma, para los distintos grupos sociales y para las comunidades mudéjares, de densa implantación en algunas comarcas, como el valle de Elda.

\section{FUENTES DOCUMENTALES E IMPRESAS}

Para Elche, igual que para Orihuela u otras localidades del territorio, la principal fuente documental son las actas de las reuniones del Consell ilicitano, conservadas desde la década de los años setenta, en las que encontramos abundantes noticias sobre ordenanzas y reglamentos en torno a la ganadería local, además de los pleitos generados por los enfrentamientos entre agricultores y ganaderos, o por los abusos de los ganados forasteros, generalmente de la ciudad de Valencia y de los municipios del entorno. A ello se añaden los datos de caracter fiscal, procedentes de las sisas o de las rentas de la señoría, donde también hay noticias referentes a la ganadería, estos últimos conservados en el Archivo del Reino de Valencia, en la sección del Maestre Racional.

La historiografía local apenas prestó atención al tema gandero y autores ilicitanos «clásicos» como Pedro Ibarra, en su trabajo sobre «Elig» aparece preocupado por ofrecer una pintoresca y variada visión de lo que fue Elche en la Edad Media, sin hacer hincapié en las actividades profesionales de los ilicitanos, y apenas encontramos alguna cita documental sobre la ganadería, pero sin ninguna

\footnotetext{
1. El tema de la ganadería en las comarcas septentrionales valencianas ha generado una abundante bibliografía, de la que entresaco algunos títulos recientes. BARREDA I Edo, P., «Llibre de Capítols d'Herbatges de la Tinença de Culla (1805)», en Boletín de la Sociedad Castellonense de Cultura, T. LXII, julio-diciembre (1986), pp. 447-562; Guinot Rodríguez, E., «La ramaderia del Maestrar Medieval: Entre l'expansió i la crisi», Estudis Castellonencs, 5 (1992-1993), pp. 255-274; SÁNCHEZ AdELL, J., «Algunos aspectos de la práctica ganadera medieval en tierras castellonenses», en Estudis Castellonencs, 5 (1992-1993), pp. 349-394; SÁnchez Adell, J., «Ganadería porcina medieval en Castellón», en Millars. Espai i Història, XV (1992), pp. 71-80; SÁnchez Adell, J., «La ganadería medieval en Castellón de la Plana. Materiales para su estudio», en Vida rural i ramadera, a cura de G. Colón y J. Sánchez Adell, en Boletín de la Sociedad Castellonense de Cultura, T. LXXV, Castellón de la Plana, julio-diciembre, 1999 (aparecido en 2001), pp. 721-782.
} 
aclaración del contexto en el que se enmarca, simplemente como una más de las muchas «curiosidades» que recoge de este período ${ }^{2}$. Este trabajo fue reproducido en el libro «Elche. Materiales para su historia $»^{3}$, obra en la que toda su atención se centró en la arqueología de la villa y de su término, en particular en el período clásico, pero que nada aporta al conocimiento de la ganadería medieval.

Alejandro Ramos Folques, en fecha más reciente y con otra metodología, más moderna, ha dedicado su labor y obra investigadora a Elche, en sus distintas etapas de la Historia, entre ellas la medieval, y en sus publicaciones encontramos también alusiones dispersas a la ganadería, como es el caso de la creación de un tribunal de la mesta en 1382, los pleitos ganaderos con Valencia, el bovalar, etc., pero sin un estudio metódico de la ganadería en la villa en el periodo que ahora nos interesa $a^{4}$.

Entre los historiadores foráneos, hay que citar las obras de $\mathrm{M}^{\mathrm{a}}$. T. Ferrer i Mallol sobre los mudéjares de la gobernación de Orihuela, fundamentales para el conocimiento de esta minoría en las comarcas meridionales del reino, pero en ellas apenas hay alguna referencia suelta al ganado de los musulmanes ilicitanos, dado que se centra sobre todo en las comunidades del valle de Elda ${ }^{5}$. En cambio, es de consulta obligatoria su trabajo sobre «les pastures $i$ la ramaderia a la governació d'Oriola», en el que utilizando las fuentes documentales del Archivo de la Corona de Aragón, que conoce a la perfección, nos presenta una exhaustiva síntesis de la ganadería en las comarcas meridionales del reino de Valencia durante el siglo $\mathrm{XIV}^{6}$.

Mención especial merece el trabajo de J.A. Barrio Barrio en torno a la regulación de los pastos en Orihuela durante el siglo Xv, porque nos va a permitir comparar la actuación de las autoridades de la capital de la gobernación con las del señorío limítrofe que era Elche ${ }^{7}$. También en otro trabajo del mencionado

2. Ibarra y Ruiz, P., «Elig. Noticia de algunas instituciones y costumbres de la Edad Media», III Congreso de Historia de la Corona de Aragón, Valencia, 1923, II, pp. 1-42.

3. IBARRA y RuIz, P., Elche. Materiales para su historia. Ensayo demostrativo de su antigüedad e importancia histórica, Cuenca, Tallesres tipográficos Ruiz de Lara, 1926.

4. Ramos Folqués, A., Historia de Elche, Elche, 1970. y Elche, 1987; Ramos Folqués, A., La industria, el comercio y la agricultura en Elche, Elche, 1974.

5. Ferrer i Mallol, M $M^{\mathrm{a}}$ T., Les aljames sarrä̈nes de la Governació d' Oriola en el segle XIV, Barcelona, C.S.I.C.-Institució Milà i Fontanals, Barcelona, 1988. Una carta de la reina Leonor de Sicilia se hacía eco de las dificultades de los moros ilicitanos por la tala de sus campos y por «la presó de vostres persones e bèsties», p. 120.

6. Ferrer i Mallol, M ${ }^{\mathrm{a}}$ T., «Les pastures I la ramaderia a la governació d'Oriola», en Miscel·lània de Textos Medievals, 7 (1994), pp. 79-139.

7. BARrio BARrio, J.A., «La ganadería oriolana en el siglo XV: la regulación de los pastos», en Cuadernos de Investigación Geográfica, 12 (1994), pp. 247-254. 
autor en torno a la normativa municipal en torno a la producción y el consumo en la gobernación de Orihuela, se encuentran algunas generalidades sobre la ganadería en Orihuela, aunque sin referencias a Elche ${ }^{8}$.

Por último están mis propias investigaciones en torno al tema ganadero en las tierras alicantinas, que llamó mi atención ya hace algún tiempo, al adentrarme en el conocimiento de la economía agropecuaria de esta zona, donde hay apartados específicos para el ganado9 , sin olvidar el capítulo que en mi estudio sobre la morería de Elche dedico a la actividad ganadera de los mudéjares ${ }^{10}$.

\section{EVOLUCIÓN HISTÓRICA. PRIVILEGIOS EN TORNO A LA GANADERÍA}

Es evidente que existió una ganadería durante la etapa de dominio musulmán, pero nada sabemos de ella, y lo lógico es pensar que tras el pacto de Alcaraz de 1243 los mudéjares siguieran con sus ganados como hasta entonces, pues así lo reconocían los pactos de capitulación. Es posible que existieran lazos entre los cristianos de la Corona de Castilla y los musulmanes que vivían en el reino de Murcia antes de la conquista, al menos al nivel de la utilización de pastos por parte de los cristianos en los meses de invierno, en aquellas etapas en las que la paz predominaba en la frontera, como por ejemplo hicieron los ganados del monasterio cisterciense de Poblet, que a comienzos del siglo XIII obtuvieron permiso del gobernador almohade de Valencia para pastar en la comarca castellonense del Maestrat, entonces bajo dominio musulmán. Pero nada sabemos para las comarcas ilicitanas. Aquí, ante la imposibilidad, por ahora, de remontarnos a fechas anteriores, el punto de partida hay que situarlo durante las décadas siguientes a la conquista/incorporación de estas tierras ilicitanas, señorío del infante don Manuel, y si en ellas la población mudéjar siguió siendo mayoritaria en el territorio y, con ella, también sus formas de vida, el proceso de cambio evolucionó de manera más rápida a partir de la revuelta mudéjar de 1264 y su represión en 1265 y 1266 por Jaime I de Aragón, que recuperó el reino de Murcia para el monarca castellano. Ello provocó una aceleración del proceso repoblador, consciente el monarca castellano, Alfonso X el Sabio, de la trascendencia que tenía incrementar el control cristiano de estas tierras del reino de Murcia, entre las que figuraba

8. BARRIO BARRIO, J.A., «La regulación municipal de la producción y el consumo en la gobernación de Orihuela, un espacio fronterizo», en Aragón en la Edad Media. Rentas, producción y consumo en España en la Baja Edad Media, Zaragoza, Universidad, 2001, pp. 19-46.

9. Hinojosa Montalvo, J., «La economía agropecuaria alicantina en tiempos de Alfonso X: aproximación a su estudio», en Anales de la Universidad de Alicante. Historia Medieval, 6, Alicante, 1987, pp. 159-172; «Aproximación a la ganadería alicantina en la Edad Media», en Anales de la Universidad de Alicante. Historia Medieval, 9, 1992-93, pp. 161-178.

10. Hinojosa Montalvo, J., La morería de Elche, Zaragoza, Instituto de Estudios Turolenses, 1994. 
el señorío de don Manuel. En Elche, los musulmanes, se habían sublevado contra las duras condiciones del señorío de don Manuel, pero éste, hábilmente y con el fin de seguir manteniendo su nivel de renta, perdonó a los sublevados y les garantizó sus privilegios. Pero ello no pudo impedir que la sociedad feudal se constituyese en la dominante y los mudéjares pasaran a una situación de subordinación y de discriminación, reducidos al marco de la morería urbana y algunas alquerías en la huerta. Intentar conocer cuál fue la importancia de la ganadería en este siglo XIII, tanto entre cristianos como entre musulmanes, es imposible por la ausencia de fuentes, pero nada permite deducir que fuera la ocupación principal de unos y otros, centrada en la tierra y en las labores artesanas.

Las exigencias de la renta feudal y el consumo urbano de Elche determinaron la orientación de buena parte de los cultivos, centrados en los cereales y el viñedo, cuyos excedentes se dedicaban a la exportación, sobre todo a la deficitaria ciudad de Valencia ${ }^{11}$, igual que otros artículos que eran la base de una interesante artesanía local, como el junco o el esparto, en tanto que los productos hortícolas abastecían las mesas de los vecinos de productos frescos y de consumo diario. Aceite, higos, dátiles, formaban parte también de esta dieta, pero del análisis de la renta señorial se desprende con claridad meridiana la importancia que tenían los granos panificables: trigo, cebada, panizo, etc. La necesidad de tener bien abastecida la localidad - la seguretat de la carn, como se la conocía- explica en buena medida el desarrollo ganadero de una pequeña localidad como Elche. No hay noticias de que la lana alimentara una industria textil importante, aunque sí que sería la materia prima de una artesanía doméstica, complemento de la agricultura $^{12}$.

Pero no debemos olvidar que el término de Elche, como toda la comarca, posee unas condiciones naturales, de clima y edafología, que hacen que no todo el territorio sea susceptible de ser cultivado, máxime en aquellos siglos de tan baja densidad demográfica, en que el perímetro agrario sólo abarcaba los espacios más próximos a la villa. Quedaban, por tanto, extensas superficies de terreno yermo, de marjales y de carrizales, que eran susceptibles de ser aprovechadas para pastos, incluso después de las roturaciones y ampliaciones del agro durante estos siglos bajomedievales. El buen clima invernal favorecía, por lo demás, la llegada de ganados trashumantes de Aragón, Castilla y del propio reino de Valencia, que bajaban a estas tierras más cálidas durante el invierno, y que se convirtieron en

11. Cueves Granero, A., «Abastecimientos de la ciudad de Valencia durante la Edad Media», en Saitabi, XII, (1962), pp. 141-168.

12. Hinojosa Montalvo, J., «La industria en Elche en la Baja Edad Media», en IX Jornades d'Estudis d'Història Local. La manufactura urbana i els menestrals (s. XIII-XVI). Palma de Mallorca, 1991. pp. 83-96. 
una fuente de ingresos fiscales, pero también de tensiones y problemas con las autoridades y el vecindario por los abusos cometidos.

El desarrollo de la ganadería en Elche y Crevillent fue apoyado por la Corona mediante diversos privilegios, sobre todo teniendo en cuenta la situación fronteriza de la villa y lugar indicados, con el peligro que ello suponía para los pastores y ganados. Así, el 12 de septiembre de 1369 Pedro IV concedió un guiaje y salvoconducto a los ilicitanos y sus ganados, que no podrían ser marcados o confiscados ${ }^{13}$. Esta disposición se incluye dentro de las medidas dadas por la Corona para la recuperación económica de las comarcas meridionales valencianas, muy afectadas en lo económico por la reciente guerra de los «dos pedros» entre Castilla y Aragón.

Para el siglo Xv, J.A. Barrio señaló cómo en la vecina Orihuela uno de los aspectos más interesantes de su economía agropecuaria fue la progresiva privatización de los pastos, como consecuencia de la consolidación de las familiaslinaje, proceso que para Elche todavía está por estudiar, pero que todo apunta a una evolución un tanto diferente, aunque no radical, dado que, mientras que en el término de Orihuela abundaban los señoríos privativos de la nobleza local, como era el caso de Albatera, La Daya, etc., en los que los señores establecieron bovalares particulares, en el caso de Elche se trataba de un señorío unitario, por lo que los particulares pocas posibilidades tuvieron de apropiarse de los pastos del señor o del municipio, aunque lo intentaron y algunos de ellos, señores de pequeñas alquerías dispersas por el término, lo consiguieron, como veremos al hablar de los bovalares.

Durante la segunda década de la centuria parece que el ganado ilicitano debió experimentar un crecimiento en el número de cabezas, a tenor de la propuesta del Consell de ampliar en noviembre de 1414 los límites de los bovalares.

\section{LOS PROPIETARIOS DE GANADO}

La fragmentación de las fuentes documentales impide establecer la sociología del mundo ganadero, aunque a través de las operaciones de venta de ganado podemos saber algo de estos propietarios de reses. Por un lado nos encontramos con aquellos particulares que poseían algunas cabezas de ganado como complemento de su economía doméstica, sin que la ganadería ocupe un lugar destacado ni en la profesión ni en la propiedad personal. Otro grupo sería el de gente de la clase media local, poseedores de rebaños de tipo medio, de unos centenares de cabezas, lo que les permitía especular con ellas a través de la compra-venta de las mismas. Es el caso de Joan Ferràndez de Mesa, notable miembro de la so-

13. A.C.A. C. reg. 917, fol. 190 r-v. 12-9-1369, Valencia. 
ciedad ilicitana, que en 1431 era lugarteniente del procurador de la villa y tenía destinados al abastecimiento de la villa un rebaño de 250 cabezas, entre carneros y borregos. Son individuos como Berenguer d'Alvado, que fue mensajero del Consell en los años ochenta, y que en 1486 vendió 307 ovejas a dos vecinos de Jijona, como veremos en otro apartado. Entre estos personajes de la oligarquía local hay también notables comerciantes como Ferrando de Madrit, que en la década de los ochenta del siglo xv fue varios años asegurador de la carne, lo que le permitió especular con la compra-venta de ganado. Esta oligarquía local presenta una gran capacidad para adaptarse a las fluctuaciones de la coyuntura, buscando la ganancia rápida, a la vez que su control del poder municipal le permitía general una legislación propia que beneficiaba sus intereses ganaderos, bien a través de «establiments», bien a través de la defensa de los espacios acotados frente a los abusos del señor o de los ganados forasteros, en particular los de Valencia. Se trata de un sector social influyente, que era el que se beneficiaba también de la comercialización de los productos ganaderos, desde el suministro cárnico a la venta de lana y cueros.

Así mismo, el propio señor de la villa, Gutierre de Cárdenas, o su procurador, Juan de Luján, eran propietarios de ganado, como se desprende de la venta de 303 carneros en mayo de 1486 a varios mercaderes de Valencia, operación que recojo en otro apartado.

Tampoco faltaron las mujeres, como Damiata, viuda de Francesc Pérez, que en julio de 1484 compró 133 cabezas de ganado a Martín de Úbeda, de Yeste.

El clero ilicitano era propietario de ganados, aunque desconocemos cualquier noticia referente a su tipología interna. Posiblemente fueran los párrocos y el prior del convento de la Merced los dueños de estos ganados, pero nada podemos precisar, dado que la única noticia conservada es una carta leída el 20 de abril de 1371 ante el Consell, en la que se daba cuenta a los allí presentes de la solicitud manifestada por el obispo de Cartagena, pidiendo a las autoridades municipales que se levantara el embargo del ganado de los clérigos. Los jurados acordaron resolver pronto el asunto del beneficio de Santa María, pero nada más sabemos del tema ${ }^{14}$.

En alguna ocasión, -sobre todo se observa en el ganado mayor, el de labranza-, se daba el caso de compartir la propiedad de un mismo animal, como el potro adquirido el 4 de marzo de 1498 por Ferrando Quirant y Sebastià Espí, por citar uno de los muchos ejemplos que ofrece la documentación.

Es imposible dar unas pautas generales sobre el número de cabezas que componían estos rebaños, porque sólo hay datos sueltos, y los habría de todos los 
tamaños, desde unas cuantas cabezas a varios centenares, acorde con la riqueza personal del propietario. En marzo de 1417, por ejemplo, vemos como los jurados autorizaron a los aprovisionadores de la carne Francesc de Mealla y a Nicolau Bonmatí, y a Beneito Bancaller y a Macià Cornellà, arrendadores del diezmo del carnaje, a poder llevar por los «mijans»-lindes- de la huerta 100 corderos cada uno en un rebaño, destinados a aprovisionar la villa, en el marco temporal que iba desde Pascua a San Juan ${ }^{15}$.

Otros datos sobre estos rebaños proceden de los recuentos efectuados por los jurados con motivo del aprovisionamiento de carne de la villa. El 14 de febrero de 1431 Bernat Bonmatí, Justicia, Sancho Sánchez de Lorca y Berenguer Quexans, jurados, fueron a inspeccionar los carneros de la carnicería que estaban en un solar o corral de Lluís Codinats, presbítero, encontrando 184 cabezas, entre carneros y borregos. El día 16 fueron al corral de Joan Ferrández de Mesa, que estaba cerca de la «plaça o eres» de Santa Llúcia, donde contaron los carneros del interesado, encontrando 250 cabezas de carneros, borregos y un cabrón ${ }^{16}$. En febrero de 1435 se compraron a Martí Tarí los 150 carneros y 12 cabrones que tenía en su rebaño, o los 203 carneros del rebaño que Joan Ferràndez de Mesa tenía en su corral. En el contrato de seguro de aprovisionamiento del año 1453 los jurados exigieron al asegurador que tuviera dos rebaños de 220 cabezas de carneros cada uno, además de otro de ganado lanar de 450 cabezas.

En cuanto a las formas de explotación de este ganado lanar tan sólo se conserva una noticia en los protocolos notariales del año 1481, referente a la formación de una compañía entre Salvador de Cecília, de Elche, y el carnicero alcoyano, Francesc Pérez, que se repartirían los beneficios a medias. Fueron 76 cabezas, que vendieron al moro Rovino ${ }^{17}$. Hay otra noticia de compañía, pero en este caso se trata de ganado porcino. El 2 de diciembre de 1480 Pere Gonçálbez estableció un contrato de tres años y entregó 30 cerdos, la mitad a cada uno de sus socios, Sancho García y Juan d'Alcaraç, además de otros 30 cerdos que Gonçálbez recibiría el primero de marzo de cada año y que le devolverían mejoradas, salvo que quisieran comprarlas antes de la Navidad de $1482^{18}$. De Pere Gonçálbez sabemos que era originario de la villa castellana de Uclés, pero entonces ya estaba avecindado en Elche, y era traficante en ganado porcino, pues el 9 de abril de 1481 pagó 925 sueldos a Francesc Julià por 74 cerdos, a 12 sueldos y medio la unidad. Juan d'Alcaraç sería de origen castellano, como denota su apellido, aunque instalado en Elche, y sus relaciones

15. A.M.E. Manual de Consells, 3. 7-3-1417, Elche.

16. A.M.E. Manual de Consells, 7. 14-2-1431, Elche y 16-2-1431.

17. A.M.E. Manual de Consells, Protocolos notariales, $n^{\circ}$ 9, fol. 263 r. 28-11-1481, Elche.

18. A.M.E. Manual de Consells, Protocolos notariales, $n^{\circ}$ 5, fol. 50 r. Los cerdos los comprarían a 16 sueldos por cabeza. La sociedad comenzaba a funcionar a partir del 1 de marzo de 1481. 
con Castilla hicieron que fuera nombrado procurador del honrado Pere Martínes de Lillo para comprar en diciembre de 1486 cerdos en Castilla ${ }^{19}$.

El mundo ganadero estaba rodeado de un ambiente peculiar, caracterizado por la movilidad, el ejercer su actividad al aire libre, en plena naturaleza, donde la soledad es, a menudo, la compañera del pastor, un ambiente casi marginal y poco controlado -a pesar de la normativa oficial-, y que por eso mismo se prestaba a ser refugio de marginales. Conscientes de estas circunstancias, las autoridades de Elche en una orden del 29 de marzo de 1416 prohibieron que ningún dueño de rebaños o pastores, cristianos o mudéjares, acogieran en sus hatos a personas de mala fama ni les dieran provisiones (pan, comida o bebida), bajo la pena de 10 morabatines $^{20}$.

\section{LOS PASTORES}

El pastor es un personaje anónimo, que apenas ha dejado huellas en la documentación, por lo que seguirle la pista es una tarea que requiere mucha paciencia, de ir acumulando poco a poco noticias dispersas. No son muchos de los que nos han quedado noticias, como un tal Beneito Gil, que aparece como testigo de la carta de franquicia concedida por el Consell en marzo de 1429 a Alfonso de Vilaquirant, mayor y vecino de Elche. Otro pastor, documentado en febrero de 1431, fue Adam Martínez, que se encargaba de conducir el rebaño de 250 cabezas propiedad de Joan Ferràndez de Mesa.

Y así vemos lo arriesgado de la profesión, sobre todo porque tenía que pasar mucho tiempo sólo, en territorio despoblado, sin más compañía que algún que otro mozo, cuando lo había, y los perros. El riesgo de ser objeto de violencia era alto, sobre todo en zonas con grandes extensiones vacías de gentes, como era la gobernación de Orihuela, donde el bandolerismo y los ataques de de castellanos y granadinos estaban a la orden del día. Conocemos un caso de esta violencia, en el que los protagonistas fueron varios vecinos de Elche, entre ellos un tal Guillem de Menargues, que fueron absueltos y perdonados de toda pena civil y criminal por el asesinato de Eximén Mateu, pastor de Pere Masquefa, vecino de Orihuela. Jaime II, sin embargo, se enteró de que Guillem Masquefa, que fue Justicia de Orihuela y sería pariente del amo del pastor, retuvo cierta suma de dinero de los bienes de Guillem de Menargues y no la había anotado en sus cuentas, por lo que ordenó el 19 de febrero de 1321 al citado Guillem Masquefa la devolución a Menargues de la suma retenida ${ }^{21}$.

19. A.M.E. Manual de Consells, Protocolos notariales, $n^{\circ}$ 10, fol. 121 v. 7-12-1486, Elche.

20. A.M.E. Manual de Consells, 3, fol. 389 v.. 29-3-1416, Elche.

21. A.C.A. C. reg. 219, fol. 241 r. 19-2-1321, Valencia. 
El ganado vacuno estaba a cargo de «vaquerizos», como Joan Aznar, al que los jurados de la villa pagaron 6 sueldos el 29 de marzo de 1489 por llevar un toro a la villa para agarrocharlo, celebrando así la toma de Vélez Málaga por Cárdenas, el señor de Elche.

La presencia de ganados foráneos en el término ilicitano era alta desde el último cuarto del siglo XIV, con la consiguiente presencia de pastores en los mismos. Ello planteó en momentos puntuales problemas con el consumo de granos, cuando había escasez de los mismos, y vemos como 18 de diciembre de 1413, ante la prohibición de sacar trigos de la villa y su término, el concejo prohibió a los dueños y mayorales de los rebaños forasteros sacar trigo en grano, en harina o en pan cocido para sus pastores, sin el correspondiente albarán. La razón era que, con la excusa de ser para sus pastores, se llevaban el trigo fuera de la villa ${ }^{22}$.

A veces es un siniestro ocasionado por un pastor el que nos permite seguir su pista en la documentación. Esto fue lo que sucedió el 20 de febrero de 1431, cuando ante el Consell de la villa se presentó Joan Catorce, ganadero de Cocentaina, con el fin de que se le perdonara a Jaume Pascual, pastor suyo, natural de Ontinyent, cualquier pena de la que fuera acreedor por el incendio que ocasionó en la partida del Portixol, gracia que le fue concedida.

Acompañaban a los pastores los perros de cabaña (ca de cabanya), también llamados cans de bestiar, que no sólo se encargaban de proteger al ganado, sino que su papel más importante era atacar y matar a los lobos y otras alimañas, tan abundantes en nuestros montes a fines de la Edad Media. Recordemos que las autoridades ilicitanas, igual que las de Alcoy, Orihuela u otros municipios, recompensaban con una suma de dinero cada lobo o camada de estos cánidos que se presentara ante las autoridades.

Aún cuando no ha dejado huellas documentales, la sal tenía una importancia considerable en la ganadería y sus derivados. Además de su empleo familiar para la salazón de los alimentos, servía para conservar la carne, sobre todo la de cerdo, y para salar los quesos, desempeñando un complejo papel como deshidratante, fijador de la humedad, conservador, selector y condimentos. También, por supuesto, era un producto de primera necesidad para el ganado, grueso o menudo. La sal permite criar mejores animales, que producen más y son más inmunes a las enfermedades. La sal es un preservativo y un estimulante. La sal que utilizaban los ganados ilicitanos y los que pastaban en su término procedía de las salinas del término, las de Santa Pola, o las cercanas de La Mata, en el de Orihuela.

22. A.M.E. Manual de Consells, 3. 8-12-1413. La pena era de 60 sueldos y la confiscación del grano. 


\section{LAS ESPECIES GANADERAS}

Igual que en el resto de localidades de la gobernación oriolana, en Elche las especies habituales de ganado eran las ovejas, carneros, bueyes, cabras, cerdos, vacas, caballos y mulos. Ello venía determinado en buena medida por el consumo diario de la población, siendo la carne de carnero, cabrón y cerdo las que más se consumían, estando gravada su compra y venta desde el siglo XIV con una sisa $^{23}$. Los jurados se encargaban de velar que el mercado estuviera siempre bien abastecido de carne, lo que fue habitual en el Elche medieval. Así, vemos como el 16 de marzo de 1427 el Consell autorizó a Macià de Cornellà, vecino, a que pastara en las medianeras de la huerta 400 corderos para abastecer la villa.

El ganado menor, lanar y cabrío, era el más abundante en Elche, como en otras localidades.

El «bestiar gros» incluía a los bueyes, vacas, toros, rocines, mulos, asnos y caballos, y eran la fuerza de tracción indispensable para el trabajo agrícola, pero también para el transporte, sin olvidar la importancia que caballos y rocines tenían como elementos de diferenciación social y como propiedad indispensable si se quería acceder a los principales cargos de gobierno municipales.

El ganado vacuno no ha dejado muchos testimonios documentales, ya que su importancia era menor que el de otras especies, aunque como veremos a lo largo de este trabajo hay menciones a rebaños de vacas de vecinos de la villa o de la aldea oriolana de Catral. Otras noticias se refieren a contratos ganaderos, como la entrega hecha el 26 de agosto de 1480 por Maçot Manç, moro de Elche, a Ginés Pérez, de Orihuela y residente en Almoradí, de dos vacas que éste se encargaría de «messonejar» por espacio de cuatro años de todo lo que necesitaran. La ganancia se repartiría a medias, devolviendo Pérez las vacas al final del contrato. En caso de no poder hacerlo pagaría 50 reales por cada una. En otro contrato del 28 de enero de 1480 se alude a la obligación contraída por Antoni Baró, de Almoradí, que prometía devolver al moro ilicitano Çaat Poruig cuatro vacas que recibió, u otras igual de buenas o doscientos reales y la mitad de las ganancias $^{24}$.

Las noticias que hayse refieren, sobre todo, a la compra de alguno de estos animales para «agarrotxar-lo» durante las fiestas locales, como los 125 sueldos pagados por un «toro» que se compró el 31 de mayo de 1487 a mosén Francesc Masquefa para agarrocharlo ${ }^{25}$. La guerra de Granada dio lugar a varias corridas

23. Barrio Barrio, J.A. y Hinojosa Montalvo, J., «Las sisas en la gobernación de Orihuela durante la Baja Edad Media», en Anuario de Estudios Medievales, 22, (1992), pp. 535-579.

24. A.M.E. Manual de Consells, Protocolos notariales, $n^{\circ}$ 9, fol. 121 r.

25. A.M.E. Manual de Consells, Manual de Consells, 18, fol. 17 v. 
de toros en Elche para celebrar la toma de algunas importantes plazas, campañas en las que participó Gutierre de Cárdenas, el señor, como en la conquista de Vélez Málaga o de Loja.

El ganado equino, igual que en otras localidades, tuvo una gran importancia en Elche y se convirtió en el protagonista de los actos de compra-venta, pues en los protocolos notariales que se conservan entre 1473 y 1506 se documentan nada menos que trescientas quince transacciones con estos animales, moviendo un capital por valor de 46.500 sueldos, tan importante como el que se destinó a la compra de censales y propiedades urbanas. La mayoría de las operaciones giran en torno a animales de trabajo, comprados o vendidos habitualmente por unidades. De los 266 animales vendidos la mayoría son mulos (74, con el 28,57\%) y asnos (62, con el 24,13\%), que en ocasiones son también permutados (16 y 14 unidades respectivamente), utilizándose para el trabajo.

Los rocines (no aparece la palabra «cavall») ocupan un lugar importante en las transacciones, con 51 animales vendidos y 16 permutados $(21,27 \%)$, calificándose alguno de ellos como «de sella», es decir, aptos para ir ensillados. Le seguían los burros («someres») con 38 unidades (12,06\%), muy utilizados en los desplazamientos, los machos, con 16 unidades, y las yeguas con quince. Potros y pollinos apenas tienen protagonismo, con 6 y 4 animales vendidos.

Los precios más altos los tenían los machos, con una media de 287 sueldos, oscilando entre los 180 y loas 400. Aunque algunos rocines alcanzaron los 455 sueldos, la media, en cambio, fue inferior, con 170 sueldos, ya que los hubo que fueron valorados en 50 sueldos. A los machos les seguían en valor medio los mulos, con 222 sueldos, oscilando entre los 120 y los 380 sueldos por animal. Los potros estaban en el escalón inferior, aunque lejos, ya que la media fue de 153 sueldos, oscilando entre los 120 y 220 sueldos, mientras que asnos, burros y pollinos tuvieron un valor medio de 72,63 y 41 sueldos, respectivamente.

La ganadería porcina era un capítulo importante en la economía doméstica de la Europa bajomedieval y Elche no era una excepción. El cerdo era una de las principales fuentes de carne, gracias a ser un animal omnívoro y de crecimiento rápido. El hecho de poder conservar en sal su carne dio gran importancia a su crianza, consideraciones que son válidas hasta fechas recientes. El problema radicaba en la abundante cabaña porcina y la escasez de tierras disponibles para su alimentación, lo que planteaba un conflicto de intereses con los agricultores y otros ganaderos, por lo que desde fecha temprana hubo que dictar normas punitivas para castigar las intromisiones y los daños que los cerdos, por causa de su descontrol, pudieran acarrear en las tierras sembradas, por lo que las autoridades se pasaron toda la Edad Media dando ordenanzas y lanzando pregones sobre estos animales, más prohibiendo que autorizando a que pastaran. Así, el 13 de enero de 1380 se dispuso que todo aquel que llevara un cerdo detrás de 
las bestias a su heredad, que lo tuviera atado para que no causara daño. El día 29 de febrero se prohibía meter cerdos en el campo vedado a los otros animales. La senda de Carmahadet marcaba el límite del término vedado, debiendo entrar y salir las piaras siempre por el camino de Monforte o por la Rambla, como estaba dispuesto para otros ganados, medida que fue repetida el 16 de marzo.

Las quejas de las autoridades por los daños que estas piaras de cerdos causaban menudearon, como veremos a lo largo de esta etapa bajomedieval y las encontramos en todos los municipios valencianos. En Castellón de la Plana, por ejemplo, una antigua ordenanza autorizaba a introducir hasta veinte animales en la huerta, número que con el tiempo se consideró excesivo y el 8 de agosto de 1384 se anulo dicha autorización. En estas fechas Sánchez Adell ha calculado que en la huerta castellonense podría haber un millar de cerdos, cifra acorde con el millar de fuegos que había en la villa y que nos daba un cerdo por casa por término medio ${ }^{26}$. El 16 de marzo de 1380 hubo quejas en el Consell contra Pere d'Espinosa, que tenía «porqueria de porchs» y los llevaba por la huerta, causando daño en los viñedos y en las acequias, y dado que desde antiguo estaba prohibida la entrada de los cerdos en la huerta, se vedó que entraran más arriba de la citada senda de Carmadahet, bajo pena de 60 sueldos.

En Elche, el 29 de junio de 1439 las autoridades municipales, para evitar «grans dans e mals que les porqueries fan en lo terme de la dita vila», prohibió que nadie llevara cerdos a pastar por el término, bajo la multa de 50 morabatines, repartidos en tres tercios para el Justicia por llevar a cabo la ejecución, el acusador y el dueño de la tierra. En el caso de que fuera de realengo el territorio, el tercio correspondiente al dueño del terreno pasaba a ser del Consell, que lo destinaría a la obra de las murallas ${ }^{27}$.

El 10 de diciembre de 1450 el Consell revocó la anterior ordenanza que prohibía que los cerdos entraran a pastar en los términos de la villa, bajo la sanción de 500 sueldos. Ahora la prohibición sólo afectaba a los panificables, con una multa de 60 sueldos para los trasgresores. La medida no debió dar muy buenos resultados y los abusos estaban a la orden del día, hasta el punto de que el 15 de abril de 1453 los jurados dispusieron que todo aquel que encontrara cerdos en

26. SÁnChEZ Adell, J., «Ganadería porcina medieval en Castellón», en Millars, XV, (1992), pp. 72 -80, en concreto pp. 73-74. En la nota 9 de la p. 75 recoge la preocupación por los daños que los cerdos causaban en los cultivos, reflejados en las ordenanzas de diferentes localidades castellonenses, como Benassal, Benicarló, Vilafamés, El Boixar, Vila-real, etc. En el caso de Castellón puede leerse en un establiment del Consell: com gran multitud de porchs sien tenguts per molts singulars de la present vila e aquells per la dita multitud sien fort mal guardats en tant que per los dits porchs són fetes grans tales donants grans dans e dapnatges, axí dels fruits com encara de les terres scalivant aquelles, de què la cosa pùblica és molt lesa, segons per speriència clara, que és mare de totes les coses, clarament e provat...».

27. A.M.E. Manual de Consells, 11. 29-6-1439, Elche. 
su heredad, estuviera plantada o en barbecho, pudiera degollar el cerdo o llevárselo vivo. Y si el pastor que lo guardaba defendía el degüello, que el Justicia lo metiera en la cárcel, de donde no saldría si no era mediante un juicio. El dueño del cerdo pagaría además los consabidos 60 sueldos de multa ${ }^{28}$. Todo indica que agricultores y autoridades estaban cansadas de los destrozos de los puercos. En otras localidades del reino, como Vila-real, Castellón, Benassal, etc. lo habitual era que hubiera una piara comunal o dula con el fin de evitar que los cerdos anduvieran sueltos y causaran daños en los campos, pero para Elche no he encontrado noticias similares de esta dula.

\section{ZONAS DE PASTO}

En la distribución del espacio agropecuario del término de Elche hay una clara dualidad entre el territorio en torno a la villa, de dedicación preferentemente agraria, aún cuando la huerta tenga que enfrentarse a menudo con los embates de la ganadería, y el resto del término, zona prácticamente despoblada e insegura, donde el aprovechamiento ganadero era predominante. Los pastos, igual que el aprovechamiento de los terrenos incultos del término, fueron cedidos por la monarquía a los señores cuando se produjo la creación de los señoríos, tras la conquista cristiana. La señoría se reservó la propiedad, pero cedió el uso gratuito de dichos pastos a los vecinos de la villa. En el caso de Elche, la señoría poseía ciertos lugares del término para aprovechamiento ganadero y otros usos, de los que obtenía una serie de rentas, siendo éstos: «la albufera de la dita vila d'Elg, la cèquia e almarjals d'aquella, e lo erbatge del loch appellat lo Fondo, e la deffessa del port, -en lo que hoy es término de Santa Pola-e del terme de la casa Blanca». En ellos toda la competencia era del señor y el Consell no intervenía para nada, y así lo hizo saber expresamente el 13 de marzo de 1401 el procurador de la señoría (que era la ciudad de Barcelona) a los jurados de Elche, ante las pretensiones de los vecinos de Orihuela de meter allí sus ganados y vacas, prohibiéndoles entrar dicho ganado «ne erbejar ne pescar» en estos espacios y Albufera. Se arrendaban anualmente y eran aprovechados por los ganados foráneos que se ponían de acuerdo con el procurador. Esto no siempre era del agrado de los vecinos, que en 1377 se quejaron al infante Martín, señor de Elche, alegando tener derechos a pastar y abrevar su ganado en la partida de la Casa Blanca, algo que habían hecho tradicionalmente y que ahora les negaba el baile del infante. El infante, considerando justa la petición ordenó que se informara de ello a su despensero, Jordi Joan, con el fin de que, obtenida la información correcta, tomar la 
decisión adecuada, pero, entre tanto, les concedía que durante cinco años pudieran pastar y abrevar libremente sus ganados en dicha partida, sin ninguna pena.

Las cosas se complicaron al año siguiente, 1378, pues la aljama de los moros de Elche había arrendado por dos años el herbazgo de dichas tierras a ganados forasteros, con lo que los vecinos de la villa no tenían espacio para pastar en la Casa Blanca. En su resolución del 9 de febrero, el infante dispuso que el Consell y los vecinos tuvieran «l'empriu del dit terme...segons que és acostumats a obs de lurs bestiars tan solament», pero como su despensero Jordi Joan vendió las rentas de la morería por dos años a los mudéjares de la villa, en cuyo arriendo se decía expresamente «que.ls dits moros ab lurs bestiars per los dits dos anys hajen aempriu en lo dit terme», y ello se hizo bajo juramento, acordó que también los moros disfrutasen del «empriu» durante esos dos años ${ }^{29}$.

El 4 de diciembre de 1412 el Consell acordó que Bernat Gil fuera con Marc Escuder, baile de la villa, a los Balsars y a la dehesa de la sierra del Port, ya que el baile quería amojonarlos, mostrándole por dónde iban los hitos antiguos.

También en la huerta de la villa sabemos que pacían ganados, en concreto los del asegurador de la carne, que tenía derecho a tener el ganado en la huerta mientras fuera asegurador, debiendo sacarlo al finalizar el contrato. Así se lo exigió el Consell el 15 de febrero de 1402 a Ferran Pérez y a Alfonso Quirant, que el año anterior aseguraron la provisión de carne en Elche, y una vez finalizado en Carnestoltes el seguro debían sacar el ganado o los corderos que tuvieran en la huerta, siendo castigados con una multa de 60 sueldos cada vez que entraran. Se les prohibió también sacar los corderos fuera del término ilicitano, con el fin de no quedar desabastecidos de carne ${ }^{30}$.

Las autoridades municipales concedían autorizaciones especiales al asegurador en función del espacio y el tiempo, y así el 4 de marzo de 1487 se le permitió que su ganado pudiera entrar en los viñedos desde San Miguel, una vez efectuada la vendimia, hasta el 31 de enero, cuando ya comienza la vid a dar señales de vida, y si lo hiciera pasado dicho plazo abonaría una multa de diez sueldos, además de pagar los daños ocasionados. Quedaba prohibida la entrada durante todo el año en los majuelos pequeños de uno o dos años de edad, ni el los campos de alfalfa ni de azafrán, o en trigales aptos para ser regados o con posibilidad de lluvia ${ }^{31}$.

Para proteger y recoger a los ganados y albergar a los pastores el 25 de marzo de 1382 los jurados ilicitanos acordaron hacer una majada en la Casa Blanca.

29. Ferrer i Mallol, Ma . T., Pastures i ramadería, pp. 82-83. Se reproducen los documentos en el apéndice final, $\mathrm{n}^{\mathrm{o}} 22$ y 23 , pp. 131-133.

30. A.M.E. Manual de Consells, 2. 15-2-1402, Elche.

31. A.M.E Manual de consells, 18, fol. 6 r. 


\section{El bovalar}

Era habitual que en villas y lugares hubiera una parte del término municipal acotada y amojonada, destinada para el uso exclusivo de los ganados de los vecinos. Lo primero que hay que aclarar es la terminología, ya que a menudo la documentación medieval parece presentar como sinónimas las denominaciones de «dehesa» y «bovalar», pero cada una tenía su propio contenido ${ }^{32}$. Por un lado está lo que se conoce como bovalar o dehesa boyal. El Diccionario de la Real Academia Española define boyal como: «perteneciente al ganado vacuno. Aplícase comúnmente a las dehesas o prados comunales donde el vecindario de un pueblo suelta o apacienta sus ganados, aunque éstos no sean vacunos». Por otro, lo que las fuentes califican como redonda, definida por el Diccionario como «Dehesa o coto de pasto», sin más precisiones ${ }^{33}$.

Ambos tipos de dehesa existen en Elche, cuyas autoridades definen en 1488 el bovalar con toda claridad como el terreno «per a obs de les bèsties e bestiars de laurada», o sea los animales de labranza, no para carne. En las fuentes documentales se distingue los bueyes de labor (bous de laurada), los diferentes tipos de équidos, (a los que se califica de bestiar gros) y el ganado menor, que se destinaba al sacrificio en la carnicería de la villa para el consumo de la población. Pero tales criterios no siempre se mantuvieron de forma rígida, como se desprende de la protesta hecha por el Consell en su sesión del 18 de noviembre de 1443 a la prohibición del procurador de la villa de que los carneros de la carnicería de la villa entraran en el bovalar a pastar, así como contra una ordenanza dada por el baile con los herederos de las cuatro alquerías del término referente a los ganados - cuyo contenido ignoramos-, ya que ello iba contra los fueros y libertades de Elche ${ }^{34}$. Una vez más, las cuestiones ganaderas planteaban el enfrentamiento jurisdiccional entre la señoría y el municipio, que invocaba a su favor los viejos privilegios concedidos por la Corona.

32. Joan Puig en su estudio «El Llibre de Privilegis de Catí», Boletín de la Sociedad Castellonense de Cultura, C (1929), p. 291 dice lo siguiente a propósito de tales términos: «Devesa és paraula que ve de la llatina «defensa» $i$ és terra de past tancada de paret $i$ vedada, que constituix una defensa o reserva contra les necesitats que els bestiars poden tindre en l'esdevenidor. Segons la confirmació de la carta pobla de Morella pel rei en Jaume, podien els pobladors senyalar-se un tros de terra i prohibir als demés la pastura dels bestiars en ella. Aixa cada poble o universitat es podia senyalar un tros de terra de past $i$ de bosc on no podien pasturar els ramats dels particulars sinó en determinades èpoques de l'any. S es guarda per a tota classe de bestiars la terra de past es diu «devesa»; si es guarda per a que s'aprofiten d'ella els animals grossos, es diu «bovalar».

33. J.A. BARRIO BARRIO, en La ganadería oriolana en el siglo XV, p. 249, los define así: la redonda o dehesa boyal, zona de pastos protegida por el municipio y de libre acceso para todos los vecinos, y el bovalar o dehesa carnicera, dedicada única y exclusivamente para las reses que se destinaban al abasto de las carnicerías de la villa».

34. A.M.E. Manual de Consells, 12. 18-11-11443, Elche. 
Pero el bovalar ilicitano tuvo un carácter flexible en cuanto a los animales que allí pastaban y en otros casos se destinó al ganado de labrar y al que los carniceros habían de matar, tal como se aprecia en un acuerdo municipal del 1 de febrero de 1380, en el que se decía que «los boalars deben ésser preferits per a bèsties e als moltons dels carnicers».

En los Furs se estipula la obligatoriedad de obtener licencia real para establecer un bovalar, que surgía siempre a iniciativa de los propios vecinos de la villa. Éstos, junto con las autoridades locales, el Justicia, los jurados y los prohombres, reconocían el término y elegían y señalaban el territorio que consideraban adecuado, todo de común acuerdo. El bovalar era de propiedad institucional, de la Universidad de la villa, en este caso Elche, es decir, del municipio, no de una persona física. La creación de dehesas y bovalares fue consecuencia del aumento de la cabaña ganadera y de lo limitado de los pastos, así como de la necesidad de evitar intrusismos del ganado en los campos de labor. El bovalar estaba cercano a la población, pero siempre se trataba de que estuviera alejado de los campos de labor, sobre todo de las huertas.

Todos los autores coinciden en señalar el carácter municipal del bovalar, pero lo cierto es que también los particulares hicieron bovalares en Elche en el siglo xv, testimonio del incremento de la cabaña ganadera y de los beneficios que aquéllos pensaban obtener de dicha explotación. Naturalmente, estos bovalares se hacían a costa del territorio municipal o de la señoría, lo que provocó tensiones en algunos momentos, mientras que en otros, sin saber por qué, el Consell aceptó la política de hechos consumados. Es lo que se desprende de la negativa dada por las autoridades locales el 7 de octubre de 1442, según el informe de micer Lluís Tallada, el abogado del Consell y su procurador en Valencia, a algunos particulares dueños de las cuatro alquerías en el término de Elche, para que hicieran un bovalar, dado que ello perjudicaba a la villa, y los que hicieron otros bovalares antes se habían beneficiado mucho de la señoría, algo que no debía tolerarse. Se prohibía a los señores de estos bovalares que impusieran penas a los que entrara en sus tierras panificables, dado que el conocimiento de estas transgresiones era competencia del Justicia de la villa. En definitiva, pérdida de pastizales, competencia jurisdiccional y beneficios derivados de las multas, eran causa de tales enfrentamientos, similares a los que vemos en municipios vecinos, como Orihuela.

El tamaño de estos recintos estaba en consonancia con la importancia de la localidad y con el número de ganado que estaba destinado a albergar. La concesión de dehesas y bovalares llevaba aneja la obligación de su exacta delimitación, así como la señalización con mojones del citado perímetro a fin de evitar invasiones involuntarias del ganado y que nadie pudiera alegar ignorancia. El bovalar, como las dehesas, no tuvieron un perímetro fijo y definitivo desde el 
primer momento de su creación, sino que fue variando con el tiempo, sufriendo ampliaciones y modificaciones, lo que en ocasiones podían llevar a litigios con municipios vecinos, aunque ello no se dio en Elche, dada la gran extensión del término. El recinto de Elche fue delimitado en numerosas ocasiones por las autoridades locales, que colocaban mojones para que nadie pudiera alegar ignorancia y pudiera introducir allí sus ganados. Sabemos que el 8 de octubre de 1379, ante la previsión de ganados forasteros que iban a venir a pastar, fue amojonado, siguiendo los límites que tenía antiguamente, aunque no se especificaba cuáles eran. En la sesión del 5 de noviembre de este año se dice que junto a la Torre del Pla había un campo llamado «el bovalar», en el que sólo podían pastar los ganados de la villa, y los jurados mandaron amojonarlo, prohibiendo la entrada de ganados forasteros, por lo que se notificó la prohibición a Alicante y Orihuela. El Pla sería el lugar llamado actualmente Carrús y Pla de Sant Josep. De nuevo el 16 de febrero de 1381 se acordó señalar con mojones los límites del bovalar, tarea llevada a cabo por el Justicia Pau de Malla y los jurados Gil Gascó. Berenguer Crespo y Bertomeu Ferri. Los ganados que entraran serían castigados con la habitual multa de 60 sueldos, destinada a los muros y valladares de la villa. La tarea de iluminar, de señalizar el bovalar, se repetía con periodicidad irregular, corriendo el clavario del Consell con los gastos habidos.

En años posteriores prosiguió la delimitación del bovalar, como se hizo el 6 de enero de 1401, corriendo los gastos a costa de los dueños de los animales. Así mismo, se prohibió meter ganados, salvo los de arada, en dichos límites. Ello no impidió los conflictos derivados del choque de intereses entre las autoridades y los particulares por el uso del bovalar. Un ejemplo de ello lo tenemos en mayo del año 1402. El día 11 se planteó en la reunión del Consell el caso de un hombre de paraje que tenía una alquería en la huerta de Elche, poblada con seis o más casas de moros y su correspondiente jurisdicción, la alfonsina. Desde la alquería, cuyo nombre no se dice, se podía salir al bovalar común de la villa, y desde aquí al realengo. El señor alegaba que él y sus vasallos podían tener animales en la huerta y en el bovalar, no siendo un impedimento para ello el fuero «de les pastures e del vedat», pues el ganado podía salir y entrar a la alquería por el bovalar y el realengo. Los jurados alegaban que no podían tener ganado ni en la alquería ni en el bovalar, dado que la alquería estaba en la huerta y podían damnificar a las heredades vecinas, por lo que decidieron multar con 60 sueldos al señor si su ganado pacía en las heredades de la alquería ${ }^{35}$.

No sabemos hasta qué punto el citado incidente movió la decisión del Consell ilicitano el 5 de junio de este año de que el Justicia y los jurados, Pere de

35. A.M.E. Manual de Consells, 2. 11-5-1402, Elche. 
Conchilla, Paulo Yanyes y Antoni Fira, notarios, Pere Granyena y Bertomeu Ferri, mayor, reconocieran los capítulos y dudas mencionados. Que una vez vistos determinen por donde irán los bovalares del término. También, que reconozcan la huerta y los bovalares, poniendo a punto los capítulos para arrendar la huerta.

De nuevo el 29 de septiembre de 1408 dispuso el Consell que se hiciera bovalar a continuación de los límites de la huerta de la villa, encargándose de ellos el Justicia, los jurados y diversos prohombres locales, algunos de los cuales como Bertomeu Ferri ya participó en otra actuación similar en años anteriores, corriendo el clavario con los gastos que hubiera. El bovalar podría ampliarse o reducir cuando le conviniera al Consell ${ }^{36}$. Además del coto municipal, el 14 de octubre los jurados requirieron al procurador de la villa para que señalara un bovalar conveniente, según constaba por fueros viejos y nuevos, sin perjuicio de las franquicias y fueros de la villa. De nuevo el día 18 el Consell ordenó que los bovalares fueran señalizados por el procurador, dándose un pregón prohibiendo pastar fuera de dichos límites, bajo la pena de 60 sueldos.

Unos años después, el 8 de noviembre de 1414, en presencia de Pere Ferràndez de Mesa, procurador señorial, los jurados acordaron amojonar y ampliar razonablemente los límites de los bovalares de la villa, lo que podemos interpretar como un síntoma del crecimiento ganadero. A tal fin se comisionó al procurador junto con el Justicia y los jurados Bertomeu Ferri y Berenguer de Quexans, menor. También acordó el Consell que Bernat Gil, vecino de la villa, fuera con el honrado Marc Scuder, baile, a los Balsars y a la Dehesa de la Serra del Port, ya que el baile quería amojonar dichos pastizales. La misión de Gil era indicar al baile por donde iban los antiguos hitos ${ }^{37}$. Otro acuerdo para iluminar los bovalares del término fue tomado el 5 de noviembre de 1415 .

Una nueva delimitación tuvo lugar a comienzos del año 1431, cuando, a instancias del procurador de la villa, se acordó amojonar el bovalar. El 3 de febrero el citado procurador alegó que él era de Barcelona y, dada lo grande que era la huerta de Elche, no conocía por donde iban los mojones, por lo que solicitó al Consell que le proporcionara cuatro prohombres que le acompañaran en la tarea de amojonamiento, siendo elegidos el tantas veces citado Pere Granyena, Narcís d'Esclaves, Alfons Vilaquirant, mayor, y Alfons Vilaquirant, menor, todos ellos miembros de la oligarquía local. No parece que la propuesta del procurador avanzara mucho, debido a competencias jurisdiccionales, pues el 17 de junio los

\footnotetext{
36. A.M.E. Manual de Consells, 2. 29-9-1408, Elche. Los elegidos para reconocer y amojonar el bovalar fueron, además del Justicia y los jurados, Bertomeu Ferri, mayor, Bertomeu Celam, Berenguer Crespo, el notario Pau Pérez y Joan Bonmatí.

37. A.M.E. Manual de Consells, 3, fol. 360 r. 8-11-1414, Elche. Los gastos los abonaría el clavario de la villa.
} 
jurados expusieron al Consell la requisitoria del citado procurador, pero, según fueros del reino, los jurados lo dejaron a conocimiento de aquél. Días después, el procurador Andreu de Sors seguía insistiendo en hacer los mojones de acuerdo con el Consell y algunos prohombres, pero si los jurados se negaban a darle consejo, que, en este caso, no fueran con él. El procurador alegaba que era a él a quien correspondía esta tarea, en nombre de Barcelona, señora de la villa. No sabemos cómo terminó el asunto, pero el 21 de septiembre de 1440 eran los jurados y el síndico de Elche quienes requerían al procurador para que delimitara el bovalar. Los gastos correrían, como siempre, dos tercios por parte de los cristianos y uno de los mudéjares del arrabal de la morería. Idéntico acuerdo se adoptó el 31 de agosto de 1442.

En estos recintos estaba prohibida de forma muy estricta la entrada a los ganados forasteros o de los vecinos que no cumplían la normativa legal, lo que no siempre se cumplía y las infracciones eran abundantes, seguidas por las correspondientes quejas por parte de las autoridades locales. Así, el 20 de noviembre de 1379 los jurados embargaron a Pere Navarro y a otros vecinos de Elche que querían meter su ganado en el bovalar contra lo dispuesto por el Consell. Se acordó perdonarles la pena, pero en el futuro cada vez que se les encontrara allí el ganado se le confiscaría. Otro caso similar y en la misma fecha lo protagonizó el vecino Joan Moreno, al que se le embargaron bienes de su casa, una gonella, vendida en subasta por 23 sueldos y 6 dineros. El 24 de diciembre se subastó una burra de pelo blanco, confiscada a Martí García, porque metió ganado suyo en el bovalar, incurriendo en la multa de 60 sueldos $^{38}$.

En un documento del 21 de noviembre de 1434 se dejaba bien claro esta política de embargos: «E lo justicia per guardar los dits boalars, anava en aquells ab son escrivà e saig, e al bestiar que atrobava dins los dits boalars, axí dels valencians e d'aquesta vila com d'altres, fahia degolla». Por tanto, la justicia contra los ganados invasores era expeditiva, pero siempre con testigos delante «en manera que per Justicia se salvàs ço que's fahia en guardar los dits boalars».

La conservación del bovalar era una tarea prioritaria entre las obligaciones de las autoridades del lugar, y en las Cortes del reino celebradas el año 1403 el monarca Martín I dio un fuero ordenando que los bovalares fueran claramente señalizados para evitar la entrada de los pastores. Es en este contexto en el que se sitúa la petición hecha el 14 de octubre de 1408 por el Consell ilicitano al procurador de la ciudad de Barcelona, señora del lugar, para que delimitara un bovalar en el término municipal «segons que per fur vell e nou és atorgat a cascunes viles»-referencia a los fueros tradicionales y al concedido en las recientes

38. A.M.E. Manual de Consells, 1. 20-11-1379 y 24-12-1379, Elche. 
Cortes-, ello sin perjuicio para los fueros y privilegios de la villa ${ }^{39}$. También el 27 de diciembre de 1426 los jurados instaron a Francesc de Gualbes, procurador de la ciudad de Barcelona en Elche, a que renovara los bovalares, corriendo con los gastos el clavario.

El Consell se encargaba todos los años de «il·luminar», o sea delimitar los espacios destinados a pastos municipales, separándolos de la huerta. Los gastos eran repartidos entre el municipio cristiano, que corría con dos tercios, y la morería con el tercio restante. En 1429 se encargaron de la tarea de «renovellar» los bovalares Pere de Burgos y Guillem de Soria. Nótese los apellidos de procedencia castellana.

Hubo momentos en los que la delimitación del bovalar dependió del procurador de la villa de Elche, y en la reunión del Consell del 5 de diciembre de 1434 los jurados propusieron a Joan Ferràndez de Mesa, lugarteniente de Arnau Fenolleda, procurador de la villa por Barcelona, que delimitara el bovalar en la forma acostumbrada, y que luego ellos, en nombre del Consell, propondrían al citado lugarteniente que encomendara su vigilancia a Pere Codines junto con Sepulcre, el Justicia. La petición se repitió de nuevo en 1435. En septiembre de 1437 hubo una nueva requisitoria del Consell y del alcadí y aljama de los moros de la villa al procurador para que señalizara el recinto. En el caso de que la aljama no quisiera colaborar ni en acudir al procurador ni en los gastos, el Consell se reservaba las acciones legales para percibir la citada tercera parte que debía pagar.

Para muchos vecinos cualquier lugar era bueno para llevar sus ganados, y en ocasiones ni siquiera se respetaban los lugares sagrados, tal como recoge la queja de los jurados de la villa del 15 de septiembre de 1370, diciendo que los pastores estaban mal acostumbrados y llevaban a sus ganados a pastar a los cementerios, por lo que el Consell prohibió que pacieran en los de Santa María, Sant Salvador y Sant Jordi cerdos y otros animales, com los asnos, bajo la pena de 5 sueldos, de los cuales la mitad serían para la iglesia donde estaba el cementerio y la otra mitad para el Justicia ${ }^{40}$.

La soberanía del municipio sobre el bovalar y la redonda, que hasta entonces éste había disfrutado pacíficamente, no fue admitida por la señoría de Cárdenas de forma pacífica, dentro de la dialéctica de confrontación que caracterizó su señorío. Ya un mes y medio antes de que tomara posesión, el 26 de septiembre de 1481, el Consell ilicitano en su reunión ordinaria recordó que se debía amojonar la redonda, el derecho que tenía a hacerlo y a imponer una multa de 60 sueldos a los transgresores, además de la degüella-dos cabezas por rebaño invasor ${ }^{41}$.

39. Historia Medieval. Alicante, Instituto Juan Gil Albert, 1990. Documento nº 96, p. 241.

40. A.M.E. Manual de Consells, 1. 15-9-1370, Elche.

41. A.M.E. Manual de Consells, 17. 26-9-1481, Elche. Las multas se repartían entre el Justicia y los jurados. 
El conflicto de intereses se produjo a partir de mayo del año 1488 y en el jugó un papel importante el mercader Joan Quexans, arrendador de las rentas señoriales, entre las que de forma ilegal se incluían las degüellas. Es interesante hacer constar la confusión existente a la hora de utilizar los términos bovalar y redonda. En el arriendo se especificaba que las multas en dinero o cabezas de ganado forastero (una cabeza de día y dos de noche) se regirían por la Corte del Justicia, sin que interviniera el Consell. Además, la defensa de la huerta de los cristianos contra la entrada de ganados se arrendó a un particular, que cobraba las multas, sin intervención del Consell, salvo que la recaudación por el arrendador no cubriera el precio pagado, o la guarda no se arrendara ante la falta de perspectiva de obtener beneficios. En cualquier caso, la jurisdicción de la señoría no comprendía estos terrenos, sino sólo la Casa Blanca, Balsars y la Devesa, además de la guarda (alquieda) de la huerta de la morería, arrendada anualmente.

En las divergencias de 1488 había también un trasfondo de la división y enfrentamiento vecinal con el Consell y otra en el seno de la misma institución municipal. Había un grupo de vecinos que se habían entrevistado con el Comendador y mediante la maledicencia intentaban enfrentar a los consejeros con dicha autoridad, a lo que se añadió el arriendo de las rentas señoriales a Joan Quexans, en las que se habían incluido algunas que eran del Consell. La respuesta del Comendador, enfrascado en la guerra de Granada, fue conciliadora, mostrando su deseo de no agraviar ni ofender al Consell («que es de os ayudar, honrar e azer mercedes, y no de agraviar en cosa alguna»), pero al tratar el tema del arriendo dio la solución de que fuera el Consell el arrendador, dando más precio que el que daba Joan Quexans ${ }^{42}$.

La tensión subió de tono en el mes de octubre, cuando al Consell llegó la noticia de que la redonda «que és cosa pròpria del dit Consell, qui aquell havia feta en lo terme de la dita vila e aquella acostuma a renovar cascuns anys», fue arrendada por el señor por un plazo de seis años a Diego de Aliaga, su colector de rentas. Los jurados se quejaban de que en el arriendo de las degüellas no se especificaba si se hacían por entrar en el bovalar o en la redonda, aunque Aliaga confirmó que era para ambos espacios, por lo que pidieron a Cárdenas que declarase que ni la redonda ni la degüella estaban comprendidas en el arriendo ${ }^{43}$.

En lo referente a la redonda, su establecimiento y delimitación era también competencia del Consell, y tenía un carácter permanente, pues había años en los que las autoridades no la establecían, quedando el bovalar como la única dehesa comunal en el municipio. El 20 de septiembre de 1450 el Consell dispuso que se

42. A.M.E. Manual de Consells, 19, fol. 5 r-8 r. 1-6-1488, Elche.

43. A.M.E. Manual de Consells, 19, fol. 19 r-21 r. 19/21-10-1488, Elche. 
señalizara la redonda que se había hecho en el término de la villa, según acuerdo municipal.

La diferenciación entre bovalar y redonda la tenían muy clara los jurados ilicitanos y en su enfrentamiento con Gutierrez de Cárdenas en 1488 así lo expresaron, diciendo que, de acuerdo con los fueros, cualquier localidad podía hacer su bovalar, «per a obs de les bèsties e bestiars de laurada», practicando el Justicia degüella contra los ganados forasteros que entraran en él. Además del bovalar, en Elche existía a media legua de distancia un paraje llamado «redonda», amojonado y con sus hitos, que era para pastar los ganados de la villa, especificando que el ganado que no fuera de la villa «e fos de les muntanyes», es decir de las tierras altas alicantinas, no debía entrar dentro de sus límites. La soberanía de la villa sobre sus pastos quedaba perfectamente definida frente a intromisiones del señor.

Al igual que sucedía con el bovalar, el 20 de septiembre de 1450 los jurados de la villa acordaron que se señalizara la redonda que el Consell había hecho. De nuevo a finales del año 1463 vuelve a tener actualidad el tema de la redonda. En efecto, el 20 de noviembre los jurados de la villa en una carta a Pau Rosell, procurador y baile de Elche, protestaban porque desde que él tomó posesión de la procuración gentes de fuera traían su ganado a pastar - con el permiso del citado funcionario-no sólo en el realengo de la villa, sino también en el regadío y tierras panificables, algo que no podía autorizar, dado que por fuero los herbajes del término eran para disfrute de los vecinos, y las tierras cultivadas pertenecían a particulares y ningún oficial de la reina podía arrendarlas. La villa estaba autorizada a hacer redonda o «deessa» en su término, según se acostumbraba a hacer en la ciudad de Murcia, «dels privilegis e libertats de la qual se alegen a aquesta vila». El vínculo con el pasado, cuando Elche perteneció al reino de Murcia, se seguía manteniendo casi dos siglos después, porque así convenía a los ilicitanos, igual que a las otras villas de la gobernación de Orihuela. Jaime II, tras conquistar el reino de Murcia y anexionarse buena parte del mismo, tuvo la sagacidad política de respetar los privilegios, usos y franquicias de sus moradores, además de añadirles los Furs valencianos, por lo que la situación legal de sus vasallos del mediodía valenciano se beneficiaba de esa duplicidad de privilegios consuetudinarios de la etapa castellana y de la foralidad valenciana, que invocaban según las circunstancias aconsejaran, como en este caso.

Por la carta de los jurados sabemos que en 1462 se hizo redonda, comprendiendo en aquélla sólo la mayor parte de los panificables y sembrados que estaban fuera de la huerta. De nuevo, el 23 de octubre de 1463 el Consell acordó delimitar la redonda: «comencant aquella dels pins d'En Jacme Perez, qui eren d'En Rupià, en la partida de Gibalcoy. E de ally dreta via anant la lloma a Vallvert mig jorn a l'aljup de Guillamet, qui es en lo camí d'Alacant, e d'alli anant 
dreta via a l'aljup de (ilegible) qui stà en lo cami del Cabeço Gordo, e d'allí ma dreta via per migjorn a l'aljup de la Llegua, qui és en lo cami del Port, e d'allí anar dreta via per llebeg al tollal d'En Paulo de Malla, e d'alli al fornet de Na Crespa, major, qui te davall la Baya, e d'alli anant dreta via per ponent fins a les oliveres del rey, qui són en lo camí o prop lo camí de Guardamar». La señalización se haría con bastones y «broça als caps», de forma que todo el mundo las viera claramente. Los ganados que entraran dentro de estos límites serían castigados con la pena de 60 sueldos, pudiendo usar la villa de la degüella de una cabeza de ganado de día y dos si era de noche de aquellos ganados encontrados en el interior de la redonda.

También se dispuso que fuera redonda «lo pla qui es davant la vila, anant per lo camí per ponent, lo qual és damunt l'olyvar qui està en lo dit pla a la part de tramontana fins a la horellada del barranc dels Archs de pa part de llevant. E de aly avall vers migjorn fins a la orta dels moros, lo dit pla e terres qui són en aquell, del dit barranc fins a la dita Rambla, e fins a la dita orta sia redonda», y que se hagan mojones de vigas y broza en la punta, hincadas en tierra ${ }^{44}$.

Per el lugarteniente del baile, considerando perjudicados los derechos de la señoría, prohibió a finales de 1463, bajo la pena de 500 florines, hacer dicha redonda. Se recurrió a la reina y se protestó contra dicha orden por no haberse respetado los fueros y libertades locales, por lo que pedían al baile Rosell que revocara la orden y dejara a la villa utilizar la redonda. Esta medida fue notificada a Gabriel de Santa Cilia, abogado de la villa ante la señoría, pidiéndole que trabajara para conseguir revocar dicha medida, considerada un agravio a las libertades locales. En la posdata a la carta le indicaban que la ciudad de Murcia acostumbraba a hacer redonda en su término fuera de las tierras panificables, y en ambas no entraban los ganados forasteros a pastar, tan sólo los de Elche por un privilegio real «del rey de Castella quant aquesta vila era de Castella». El 18 de diciembre el Consell acordó hacer la redonda, encargando de ello a Pere Codines, alias Sepulcro, Pere Marés de Medies, Bertomeu [...] y Arnau Bonivern, que se reunirían con el lugarteniente del baile y le comunicarían tal medida ${ }^{45}$.

El choque jurisdiccional entre el Consell ilicitano y la señoría en torno a la redonda prosiguió en los años siguientes, pues el 25 de marzo de 1465 el primero ordenó a los mensajeros de la villa que iban a ver a la reina que obtuvieran autorización para hacer una redonda en el término para pastar los ganados locales, pues en este asunto nunca había intervenido la señoría. El 26 de septiembre se

44. A.M.E. Manual de Consells, 16, 23-10-1463, Elche.

45. A.M.E. Manual de Consells, 16. 20-11-1463 y 18-12-1463. En la carta a Gabriel de Santa Cilia los jurados le piden que despache pronto al correo con el fin de que no haga gastos a la villa, ya que este año habían tenido muchos. 
tomó la decisión en firme, acordando que el Justicia y los jurados escogieran el lugar adecuado, comenzando por encima del camino de Alicante, de los pinos llamados d'En Ropia, señalizando dicha redonda por espacio de medio día hasta la loma del Palmeral, situada en el camino de Guardamar «dellà les oliveretes del rey». En la redonda podrían incluirse las tierras que los comisionados consideraran oportunas, tanto censales de la señoría como otras, prosiguiendo desde la loma del Palmeral en dirección a la villa de poniente hasta el lugar que considerasen adecuado, incluyendo el llano que había delante de la villa hasta el barranco de los $\operatorname{Arcos}^{46}$. Por un documento de 1488 sabemos que la redonda estaba a media legua de distancia del bovalar.

El municipio ilicitano intentó siempre gestionar los pastos del término y para ello utilizó diversas fórmulas. Una de ellas fue la aplicación de ordenanzas rurales, en las que se era muy restrictivo con los usos ganaderos del término. De acuerdo con tales normas los jurados podían confiscar y degollar las reses que incumplieran la normativa legal dada por el municipio. Otra opción era aumentar el número de bovalares reservados exclusivamente para los vecinos, aduciendo el aumento del consumo de carne por parte de la población.

Además del bovalar de la villa, el ganado ilicitano pastaba por diferentes puntos del término, de acuerdo con concesiones hechas por la señoría. Sabemos que el infante Martín les había concedido un privilegio -en fecha que no se especifica- para que los ganados locales pudieran pastar en el término de la Casa Blanca y beber sus aguas. El problema surgió cuando los mudéjares de la aljama arrendaron el herbaje de esas tierras a cabañas de forasteros, con lo cual los ganados de los vecinos se quedaron sin poder ir a pacer a la Casa Blanca. Ante la queja presentada por el Consell de Elche, el infante ordenó al baile de la villa que dispusiera que dichos pastos del término fueran sólo para los vecinos, como era costumbre. El problema vino porque el despensero del infante, Jordi Joan, había vendido por dos años las rentas de la morería a sus vecinos, y en el contrato se decía expresamente que los moros con sus ganados tenían esos dos años «empriu» en el término, por lo que podían hacer con tales pastos lo que quisieran. El infante Martín, en carta del 24 de septiembre de 1378 no tuvo más remedio que respetar el acuerdo, dado que fue hecho bajo juramento ${ }^{47}$.

Por un acuerdo del Consell ilicitano del 16 de marzo de 1380 sabemos que los ganados tenían prohibido entrar más allá de la senda de Carmahadet, espacio que era conocido como «el vedat» de los ganados. Los cerdos, igual que el resto

\footnotetext{
46. A.M.E. Manual de Consells, 16. 26-9-1465, Elche. «...de la dita loma del Palmeral havant, anant la dita vila de ponent fins en aquell loch o lochs que conexeran ésser fahedor, e que en la dita redonda posen lo pla qui és davant la dita vila fins al barranc dels Archs». Los gastos correrían a cuenta del clavario de la villa.

47. A.C.A. C. reg. 2067, fol. 81 r. 24-9-1378,Valencia.
} 
de ganados debían entrar y salir de la villa por el camino de Monforte o por la Rambla, como estaba estipulado.

Otros parajes utilizados para pasto eran el Saladar, los almarjales y el camino al Molar. Lo sabemos por la carta enviada el 25 de febrero de 1412 por los jurados de Orihuela a los de Elche, a propósito de la queja presentada por Domingo Pérez y Martín Pérez, vecinos de la villa y moradores de Catral, porque cuando llevaron algunas de sus vacas a pastar en los almarjales de Elche habían abonado 25 sueldos en una ocasión y 11 en otra, y que por poner el hato de las vacas a la entrada del Saladar, en el realengo, pagaron a vecinos de Elche 44 sueldos. También tuvieron que abonar 180 sueldos por tener las vacas en los almarjales, y pagaron seis jornales porque hubiera hasta 40 vacas pastando en el camino que iba al Molar. Los afectados se quejaban por el mal trato inflingido por los de Elche tan pronto como podían, y dado que, según los fueros, los marjales y las montañas eran comunes y todos podían pastar libremente en ellas y aprovechar sus aguas, sin tener que abonar ninguna suma, solicitaban la devolución de dichas cantidades, ya que, de lo contrario, tomarían las oportunas medidas para resarcirse ${ }^{48}$.

\section{Los caminos ganaderos y los abrevaderos}

Respecto a los primeros podemos decir que en el término de Elche no hay constancia de que existiera una red general de caminos ganaderos, como sucedía en otras regiones de la Península. Lo que había era una red local de assagadors (azagadores), que enlazaban con los de los términos vecinos. Los ganados forasteros los utilizaban para sus desplazamientos por concesión de privilegios reales.

Por todo el término, allí donde hubiera fuentes o posibilidad de obtener agua, se extendía una red de abrevaderos para el ganado. Para evitar daños en las instalaciones, las autoridades municipales trataron de llevar un estricto control sobre el ganado, y así vemos como el 21 de septiembre de 1438 prohibían a cualquier persona que diera agua en «gamellons» o de otra manera ni de los pozos del aljibe de la Torre del Pla ni de otros aljibes del término, bajo la consabida pena de 60 sueldos, a repartir en tres tercios entre el Consell, el acusador y el Justicia.

En otro acuerdo del 13 de octubre de 1454 los jurados dispusieron que nadie diera agua ni abrevara a cerdos, pequeños o grandes, u otro ganado lanar, cabrío, etc. en ningún aljibe del término, ni sacaran agua para que bebieran los rebaños, bajo la pena de 60 sueldos.

48. Nieto Fernández, A., Orihuela en sus documentos. II Economía y sociedad, Siglos XIV-XIX. Agricultura. Ganadería. Industria y Comercio, Murcia, 1988. pp. 83-84. 


\section{EL ARRENDAMIENTO DE LOS PASTOS}

Los dos mecanismos que se utilizaban para la explotación de los pastos eran el pago de una tasa por animal o rebaño y el alquiler de un área del término. El primero es el más antiguo y se acerca más al concepto de herbaje. Otro derecho era el que se cobraba por el guiaje de los rebaños (guidaticum).

Pero el sistema más utilizado para gestionar los pastos del término era el arrendamiento. Las condiciones variaban en los señoríos según la localización geográfica, el tipo de cultivos, la extensión, la mentalidad del señor, etc. Los términos del arrendamiento no solían variar de un año para otro, pero la especulación de los pastos hacía que el precio que debían abonar los propietarios de ganado dependiera más de las condiciones del mercado que del número de cabezas que apacentaban. En Elche, como en el resto del reino de Valencia, la explotación de los pastos era un asunto municipal, supervisado por las autoridades locales, fuera el señor, el baile o el municipio.

El arrendamiento de los pastos ofrecía importantes ventajas para la entidad interesada, como era evitar los problemas de gestión y cobro, a menudo difíciles; además, permitía saber de antemano la cantidad de dinero de la que se podía disponer. Los mecanismos de adjudicación eran similares a los de otros impuestos, como la sisa, el derecho de aduana, etc.

Al arriendo se llevaba a cabo mediante subasta pública, tras el correspondiente pregón público por la villa, fijando el día y lugar en el que se convocaba a los interesados. Ese día se procedía a la puja, tras la cual el mejor postor era ratificado como arrendador, realizando el correspondiente contrato ante el notario. En el documento se fijaba el nombre del adjudicatario, el tiempo de la concesión, la cantidad a abonar, los fiadores, los plazos en los que se debía efectuar el pago, y las cláusulas jurídicas que garantizaban el cumplimiento de lo acordado.

Por una misiva enviada el 20 de noviembre de 1463 por los jurados a Pau Rosell, escribano del rey, procurador y baile de Elche, sabemos que ni el infante Martín - cuando fue señor de la villa- ni la señoría de Barcelona arrendaban otros herbajes del término que los de la Casa Blanca con el término de Crevillent y el herbaje del Balsar, con la Dehesa del Port. El arriendo era anual y figuraba en el cabreve de la reina con las otras rentas. Los jurados mostraban su descontento hacia el procurador porque desde que había tomado posesión de la villa acudían al término gentes forasteras para pastar su ganado, no sólo en el realengo del término de la villa, sino también en las tierras panificables y de regadío, lo que no se podía consentir, dado que los herbajes del término fueron dados mediante fuero para uso y disfrute público de la villa, complicándose el tema con la creación de una redonda por el Consell, como vemos en el apartado referente a este espacio de pastos. La protesta aducía también el hecho de que las tierras panificables y plantadas pertenecían en alodio, en plena propiedad, a los particulares de la villa, 
y los oficiales de la reina no podían vender los herbajes de las citadas tierras particulares, puesto que la villa estaba autorizada a hacer redonda o dehesa en el término de la misma.

\section{LAS ORGANIZACIONES GANADERAS}

Parece que en Elche no hubo ninguna asociación de ganaderos hasta comienzos de la década de los ochenta del siglo xiv, quizá porque la escasa entidad que la ganadería tuvo la hacía innecesaria. Pero todo apunta a que tras la recuperación económica que se inició finalizada la guerra con Castilla, las autoridades municipales consideraron oportuno que la hubiera, y el 18 de marzo de 1382 el Consell acordó que cada año se hiciera una Mesta o asociación de ganaderos el primero de marzo, y «com sia cosa novella en esta vila», se dispuso que el Justicia y los jurados buscaran a algunos hombres que redactaran los oportunos capítulos ${ }^{49}$. Por tanto, no hay ninguna duda sobre la novedad que suponía esta organización, ya que hubo que buscar a gente que fuera capaz de redactar unas ordenanzas. Nótese que se le da el apelativo de «Mesta», de tradición castellana, y no el de no Lligalló, como era habitual en otras comarcas del reino de Valencia.

No sabemos si esta Mesta ilicitana llegó a funcionar, pues no hay más noticias de ella y nada se ha conservado de los capítulos que quizá se redactan.

\section{LA TRASHUMANCIA}

Las tierras de la gobernación de Orihuela, en las que se incluía Elche, eran el destino invernal de los ganados de las poblaciones conquenses, aragonesas y valencianas, y ello desde antiguo, casi con toda seguridad desde la etapa musulmana, flujo que se mantuvo tras la conquista cristiana y la incorporación del reino de Murcia a la Corona de Castilla. Torres Fontes señaló la inexistencia de noticias relativas a dicha trashumancia en las comarcas murcianas anteriores a la sublevación mudéjar de 1264 y considera dudosa que la hubiera, dada la inseguridad de la zona y el régimen de protectorado mantenido por Castilla. La vuelta a la paz en el territorio y el incremento del proceso repoblador, con la mayor afluencia de pobladores cristianos y la seguridad en estas tierras, hizo que comenzaran a llegar ganados a invernar a los campos murcianos, y por ende, quizá, a los del término de Elche. Lo que está claro es que un privilegio alfonsí del 18 de mayo de 1267 facilitaba la trashumancia aragonesa en tierras murcianas, y la Iglesia de Cartagena obtuvo otro privilegio real el 24 de marzo de 1270 para

49. A.M.E. Manual de Consells, 1. 18-3-1382, Elche. 
cobrar el diezmo de los ganados que vinieran al obispado a pacer ${ }^{50}$. Señal de que los ganados forasteros estaban ya en estas tierras.

La conquista del reino de Murcia por Jaime II provocó cambios en los espacios destinados a pastos de los ganados trashumantes, al quedar el reino de Murcia partido tras la sentencia arbitral de Torrellas (1304), con lo que los ganados que venían de fuera podía ir a los pastos de la procuración/gobernación de Orihuela y a los del Campo de Cartagena, o el término de Murcia ${ }^{51}$. El ganado que procedía desde Aragón y el reino de Valencia entraba en el término de Elche por el camino de Alicante, quedándose en el término o prosiguiendo luego hacia Orihuela, Murcia o territorio de Cartagena. Los que venían de la Mancha bajaban por el valle del Vinalopó hasta estas tierras de la gobernación murciana, en un itinerario que se remontaba a la época de don Juan Manuel y a la época de dominio musulmán. En 1303 Jaime II concedió salvoconducto a los ganados de Cuenca, Huete, Alcaraz, Molina y de otros lugares para cruzar por tierras murcianas y venir a las tierras de don Juan Manuel, es decir al término de Elche ${ }^{52}$

Aunque se refiere al reino de Murcia, Torres Fontes nos ha dejado la noticia de que en el año 1374 Enrique II de Castilla prohibió la trashumancia aragonesa, aduciendo que: «avemos sabido por cierto que por la grant fambre que es en Aragón e en el regno de Valençia» pasaban sus ganados a Castilla, «de lo qual viene a nos grand deservicio en tres maneras: lo uno por paçer ellos con sus ganados la yervas de nuestras tierras, e lo segundo porque los pastores e los omnes que con los dichos ganados andan, lo lievan e pasan a Aragón, e lo terçero que en vuelta de los sus ganados que ellos acá troxieron, que pasan a Aragón otros muchos ganados de los nuestros regnos diziendo que son suyos», por lo que se ordenó que los ganaderos de la Corona de Aragón abandonaran el reino de Castilla y sólo pudieran llevarse el mismo número de cabezas que habían entrado ${ }^{53}$. No sabemos las consecuencias que el hambre generalizada en el reino de Valencia pudo tener en la trashumancia que llegaba al término de Elche.

Buena parte de los ganados forasteros trashumantes en el término ilicitano procedían de la capital del reino, tal como atestiguan los continuos pleitos entre Elche y Valencia por las intromisiones de los ganados de la capital. Ejemplo de

50. Torres Fontes, J., «Notas para la historia de la ganadería murciana en la Edad Media», en Miscelánea Medieval Murciana, XII, (1985), pp. 142-143.

51. Ferrer i Mallol, Ma . T., Organització i defensa d'un territori fronterer. La Governació d'Oriola en el segle XIV. Barcelona, Institució Milà i Fontanals, 1990, pp. 3-9 y 49-50. Veas Arteseros, F. de A., «Notas para el estudio de la ganadería del marquesado de Villena», en Congreso de Historia del Señorío de Villena, Albacete, 1987; Martínez Carrillo, M. LL., «Caminos ganaderos murcianos durante la Baja Edad Media. Reconstrucción documental», en Anuario de Estudios Medievales, 23 (1993), pp. 75-88.

52. Ferrer i Mallol, Ma T., Les pastures I la ramaderia a la governació d'Oriola, p. 80.

53. Torres Fontes, J., «Notas para la historia de la ganadería murciana...», p. 145. 
estos ganados era el que en la primavera de 1434 tenía Andreu Ferrer, labrador y ganadero de Valencia, cuyo rebaño ascendía a 1.150 cabezas de carneros.

También Elche acogía a ganados de las localidades de la zona central del reino, como fue el caso de Bocairent. De ello tenemos alguna noticia dispersa, fruto de los pleitos que por diversas razones se plantearon. En el caso concreto de Bocairent sabemos que los diputados del brazo real en las Cortes se quejaron al rey porque los ganados de esta localidad bajaban a invernar a los términos de Orihuela, Elche y Alicante, llevando con ellos algunos animales de crianza, que habían nacido en el término de Bocairent, por lo que pagaban en esta villa el diezmo por ellos. Ahora los bailes de estas localidades del sur del reino les obligaban a abonar dos dineros por cada animal de crianza, lo que consideraban ilegal, dado que ya habían satisfecho el diezmo, por lo que pedían al monarca la abolición de dicho cobro. Alfonso V el 19 de noviembre de 1429 ordenó al baile general que, si diez años atrás no se cobraba dicho impuesto de dos dineros, que fuera declarado nulo ${ }^{54}$.

El término de Elche era paso obligado de los ganados que desde las tierras del reino de Murcia se dirigían a los pastos del reino de Valencia, de sur a norte, y de ello nos ha quedado alguna noticia dispersa, como el conflicto que se produjo con la ciudad de Murcia en el año 1303, que requirió la intervención de Jaime II. E1 23 de enero de 1304 el rey escribía a Pere de Montagut, procurador general del reino de Murcia, ordenándole que obligara al alguacil de Murcia, Arnau Millares, a la devolución de las 108 cabezas de ganado que hizo apresar por la fuerza en el término de Elche, junto a la torre de Juan de la Cañada, a los templarios de Vilella, cuyos pastores se trasladaban desde los pastos murcianos a los de Valencia ${ }^{55}$.

Tenemos algunas noticias sueltas sobre las cifras de ganados que practicaron la trashumancia, y por las cuentas de las rentas de la señoría en los años 14651466 sabemos que acudieron a invernar a Elche 8.350 cabezas de ganado lanar -casi todas-. Procedían básicamente de las localidades valencianas de la Vilajoiosa, Bocairent, Alcoy, Ayora, de Chinchilla y de otros lugares no especificados del reino de Castilla. En el invierno de 1466-1467 se contabilizaron 5.650 cabezas de lanar, sobre todo de Bocairente (el 66,37\%), Cocentaina, Xàtiva y Alcoy ${ }^{56}$. Algún ganado tenía hasta 2.450 cabezas, lo que da idea de su importante volumen. La trashumancia en los campos ilicitanos tenía, por tanto, un radio de acción comarcal dentro del propio reino, desde la Costera y comarcas centrales,

54. A.R.V. Real, 231, fol. 106 r. 19-11-1429, Sagunto.

55. A.C.A. C. reg. 131, fol. XXXIII r. 21-1-1304, Valencia.

56. A.R.V. Maestre Racional, 9761. Los pastores y ganaderos que proceden de Bocairent son: Bertomeu Forri, Joan Tallot, Sancho del Puerto, Miquel Mayques, Domingo Visedo y Andreu Visedo. 
y otro regional, abarcando las tierras manchegas lindantes con Valencia, las de Chinchilla.

Para el señor, la trashumancia era una fuente de ingresos en virtud de la concesión de licencias para pastar, a razón de cinco sueldo por centenar de cabezas. También para la villa, que percibía las quejas y las penas en dinero o en cabezas (degüella), así como un derecho de paso, de escasa cuantía -entre 10 y 37 sueldos en los años noventa del siglo XV-, abonado por atravesar el «pas nou», cuya ubicación se desconoce»»

La única noticia de la salida de ganados ilicitanos fuera del reino de Valencia es del año 1496, en que por falta de pastos llevaron el ganado a pastar al reino de Granada, donde se les exigió algún derecho que consideraban injusto. Por ello la villa envió como mensajero a Almazán a Miquel Sançano, donde estaba Gutierre de Cárdenas aconsejando al rey en las conversaciones que mantenía con los embajadores franceses en torno al Rosellón ${ }^{57}$.

\section{EL ESQUILEO}

Sabemos que las autoridades locales no estaban dispuestas a renunciar a los beneficios fiscales generados por la actividad de esquilar los ganados, por lo que el 10 de mayo de 1379 acordaron que todo aquel que tuviera ganado en la villa, lo esquilara en ella o en su término, a fin de no perder el ingreso de la correspondiente $\operatorname{sisa}^{58}$. En otro apartado referente a las utilidades ganaderas aludiré a nuevas prohibiciones de esquilar fuera para evitar que se perdiera el ingreso de la correspondiente sisa o la villa quedara desabastecida.

\section{CONFLICTOS DEL MUNICIPIO CON LOS PARTICULARES}

El ganado fue una continua fuente de conflictos y enfrentamientos entre las autoridades locales, que trataban de salvaguardar los espacios públicos y de labor frente a las intromisiones y destrozos causados por los animales. Los abusos estaban a la orden del día. Asñi, el 22 de mayo de 1386 los arrendadores de la albufera de Elche expusieron a la reina María, tutora del infante Martín, el señor de la villa, que dicha albufera se alimentaba con agua del azarbe llamado de don Manuel, que se tomaba del río Segura y discurría por los marjales del infante, y desde aquí a la albufera llamada de don Manuel por una acequia, que cada año los arrendadores habían de obrar, que eran 2.860 brazos reales o más. Pero dicha obra aprovechaba poco -se quejaban- porque Ginés de Santa Creu, habitante en

57. A.M.E. Llibre de Clavería, 1490-1495, fol. 242 r. Se pagarón al mensajero 84 sueldos por su trabajo. 58. A.M.E. Manual de Consells, 1. 10-5-1379, Elche. 
Elche, con muchas vacas suyas pacía por los ribazos de la acequia y continuamente estaba ensuciándola, sin que sirviera para nada el trabajo de limpieza y mantenimiento que se hacía, con lo que se dañaba la acequia y el pescado de la misma, que no podía discurrir libremente por la misma. La reina ordenó al baile de Elche que fuera a inspeccionar el azarbe y la acequia, y si observaba que las vacas de Ginés hacían tales males, que la limpieza y arreglo de la acequia corriera a su cargo, y si no lo hiciera que le embargara sus bienes, de forma que quedaran protegidas las rentas del infante. Al mismo tiempo debería hacer un pregón para que nadie con sus animales ensuciara dicha acequia ni el azarbe, bajo la pena que considere oportuna ${ }^{59}$.

La entrada furtiva o casual de animales en los campos de labranza era muy perjudicial para las cosechas, lo que hizo que las autoridades extremaran la vigilancia de los campos y reprimieran con severidad las infracciones. El 13 de enero de 1380 se abordó en la reunión del Consell el daño que hacían en las cebadas los pollinos que acompañaban a las bestias, por lo que se acordó obligarles a llevar bozales o a que sus dueños los vigilen de forma que no causen daños, bajo la pena de 12 sueldos $^{60}$.

Otro espacio susceptible de ser teatro de los desmanes del ganado eran las eras, por lo que el 28 de febrero de 1431 los jurados prohibieron meter ganado en la plaça de les Eres, también llamada de Santa Llúcia, de día o de noche, salvo que fuera de paso, debido al daño que los animales causaban en las eras, que eran para batir los granos. La pena a los infractores era de 5 sueldos $^{61}$

También los cerdos eran particularmente agresivos, y el 16 de marzo de ese año de 1380 se expuso en la reunión del Consell que Pere d'Espinosa tenía una piara de cerdos que iba por la huerta, causando daños en viñedos y sembrados, así como en las acequias, lo que no había sucedido con otras piaras, sobre todo porque si los ganados tenían prohibido entrar de la senda de Carmahadet arriba, mucho menos debían entrar los cerdos. Se acordó que nadie entrara piaras de cerdos dentro del «vedat» de los ganados, seto es, de la senda de Camahardet arriba, bajo la pena de 60 sueldos. Los cerdos que entraran y salieran de la villa lo harían siempre por el camino de Monforte o por la Rambla, como estaba dispuesto para otros ganados ${ }^{62}$.

Estas medidas, como era habitual, no debieron dar mucho resultado, pues el 23 de noviembre de 1381 hubo quejas porque los ganados de algunos vecinos

59. A.C.A. C. reg. 2107, fol. 55 r-v. 22-5-1386, Segorbe.

60. A.M.E. Manual de Consells, 1. 13-1-1380, Elche.

61. A.M.E. Manual de Consells, 17, 28-2-1431, Elche.

62. A.M.E. Manual de Consells, 1. 16-3-1380, Elche. 
iban por la huerta, contra las ordenanzas, en particular los corderos y carneros, que iban por viñas y sembrados. Los jurados echaban la culpa de ello a la negligencia de los guardianes de la huerta, a los que se había advertido en numerosas ocasiones de tales daños y ordenado que embargaran a los infractores, pero sin resultado. Por ello se acordó nombrar reguardia de la huerta a Bertomeu Crespo, que juró su cargo ante el Consell ${ }^{63}$. Su misión sería, sin duda, controlar a los citados guardianes.

De nuevo en 1402 vuelve a repetirse la ineficacia de los guardianes de la huerta, Jaume d'Alenzina y Pere Dezclapés, quienes en su descuido dieron lugar a que la huerta estuviera talada y maltratada por los guardianes, por lo que Bertomeu Ferri, Justicia -que ya fue jurado en los años ochenta- fuera reguardia.

\section{CONFLICTOS CON LOS MUNICIPIOS VECINOS}

Durante los siglos medievales los conflictos con las localidades vecinas o próximas por cuestiones ganaderas fueron algo habitual, y en ello Elche no fue la excepción. Ya en fecha tan temprana como el 28 de abril de 1296, desde la huerta de Almoradí, con las tropas de Jaime II en plena campaña de conquista del reino de Murcia, el rey de Aragón ordenaba al Justicia y a los jurados de Guardamar que entregaran de inmediato a sus legítimos dueños en Elche las cabezas de ganado, mayor y menor, que retenían indebidamente en la villa, tras habérselas robado $^{64}$. No se trataba de un caso aislado, pues el 13 de junio de este año el rey volvía a ordenar a los alcaldes, jurados y prohombres de Orihuela y de Guardamar que devolvieran a unos moros de La Daya las cabezas de ganado que unos días antes habían robado en dicho lugar unos almogávares ${ }^{65}$.

Tampoco faltaron los pleitos con Orihuela y sus aldeas. En la reunión del Consell del 13 de marzo de 1401 se presentó ante los jurados una carta traída por Guillem Fritos, de Orihuela, fechada el día anterior. Se expuso que ante los jurados oriolanos habían comparecido algunos vecinos de Catral y se quejaron porque estando pastando sus vacas en el término de Elche, los jurados ilicitanos les ordenaron que salieran del término y no pastaran, bajo la pena de embargo, manifestando su sorpresa por tal comportamiento. Recordemos que el embargo (penyorar, fer marques) era la forma habitual de castigar a los que infringían las normas referentes a los pastos en dehesas y bovalares, aunque muy a menudo,

63. A.M.E. Manual de Consells, 1. 23-11-1381, Elche.

64. A.C.A. C. reg. 340, fol. 52 v. 28-4-1296, Huerta de Almoradí.

65. A.C.A. C. reg. 340, fol. 132 v. Ferrer i Mallol, Ma T., La frontera amb l'islam en el segle XIV. Cristians $i$ sarraïns al País Valencià, Barcelona, C.S.I.C.-Institució Milà i Fontanals, 1988, p. 226, doc. nº 2. 
como se ve en la documentación de la época, lo habitual es que el municipio afectado repenyonara a sus castigadores para resarcirse de las pérdidas sufridas.

El mensajero de Orihuela preguntó a los jurados si ello era fruto de un acuerdo del Consell de Elche o del procurador de la villa, a la vez que les recordaba el privilegio que tenía Orihuela de poder pastar en el término de Elche y viceversa. Si las autoridades locales ilicitanas no querían que entraran ganados oriolanos en sus términos, que lo dijeran, con el fin de que los de Orihuela tomaran la misma decisión.

El lugarteniente del procurador, Pere Fernández de Mesa, oídas tales razones, respondió, que el señor de Elche tenía ciertos lugares del término reservados para sí, de los que percibía una serie de rentas, como eran la Albufera, la acequia, los marjales, y el herbaje del Fondó y de la dehesa del puerto y del término de la Casa Blanca, en los que el Consell de Elche no tenía nada que ver. El representante de la señoría dijo que no se podía probar que el rey hubiera concedido a Orihuela ni a otros del reino entrar en estos pastos, por lo que no permitiría entrar en ellos a los de Orihuela.

A continuación se pidieron testigos que hubieran visto pastar a estos ganados, y salieron algunas personas que dijeron que vieron en la albufera las vacas de un vecino de Catral y de otros de Orihuela, a la orilla de una acequia que recogía el agua de los marjales y de la acequia de don Manuel, y que las vacas hacían mucho daño al interrumpir la circulación de las aguas y en las pesquerías de la villa. El procurador ordenó a los pastores que llevaran las vacas a pastar a otros lugares, aunque no les dijo que salieran del término de Elche. Luego se escribió una carta al Consell de Orihuela, en la que, además de acusar recibo de la suya, se decía que ignoraban lo sucedido hasta la explicación del mensajero, y que hacía tres semanas Tomás Gerona, el procurador de la villa, y Domingo Sánchez, notario y procurador de la reina, fueron a la albufera con otras gentes para reconocerla y se encontraron con muchas vacas, que se decía que eran de Antoni Ivanyes, de Catral, y de gente de Orihuela, por lo que se les pidió que salieran del término, cosa que no hicieron ${ }^{66}$

No cesaron los problemas en años posteriores y ya aludimos al referirnos a los espacios destinados a pasto, a la queja presentada por dos vecinos de Catral contra el cobro indebido por algunos vecinos de Elche de determinadas sumas de dinero por dejarles pastar sus vacas en el Saladar, los marjales y el camino al Molar. El 22 de agosto de 1417 algunos vecinos de Orihuela se quejaron ante el Consell porque eran maltratados en Elche y no se les dejaba entrar con sus bestias en el término, por lo que como medida de presión se acordó que a los vecinos

66. A.M.E. Manual de Consells, 2. 13-3-1401, Elche. 
de Elche y Crevillent se les prohibiera hacer sosa y recoger junco en el término de Orihuela que quedaría sólo para su vecindario y los de sus aldeas, bajo la pena de 60 sueldos y la pérdida de la sosa y el junco.

Meses más tarde, el 27 de abril de 1418, Pere Fernández de Mesa, procurador de Elche, propuso a los jurados oriolanos que, dado que hacía tiempo que ambas villas estaban de acuerdo en permitir el pastoreo mutuo de sus ganados en sus respectivos términos y en el de Crevillent, se levantase la veda del junto y de la sosa, propuesta que fue aceptada por el consistorio oriolano por el tiempo que le pareciera oportuno ${ }^{67}$.

\section{Conflictos con Murcia}

No faltaron los conflictos que enfrentaron a las autoridades ilicitanas con el episcopado murciano por la utilización de los pastos de Elche por ganados teóricamente pertenecientes a la Iglesia. Así, el 20 de abril de 1379, los jurados recibían una carta del obispo de Cartagena que se había enterado que Bartomeu de Bonay, tesorero del infante, había embargado ganado extremeño perteneciente al obispo y a clérigos de la diócesis, indicándoles que en dicho ganado no tenían ningún derecho los clérigos parroquiales ni las fábricas, por lo que pedía que fuera desembargado, y luego el obispo pasaría cuentas con el tesorero por todo lo que le debía ${ }^{68}$.

No todo fueron conflictos y desavenencias, pues también las autoridades ilicitanas estuvieron a la altura de las circunstancias cuando se les pidió algún favor, como el 30 de diciembre de 1443, en que las autoridades locales y el gobernador general de Orihuela, así como de mosén Diego Fajardo, explicando que los ganados murcianos y los de Abanilla que pastaban en el término de Orihuela no podían hacerlo por la mucha gente que se había concentrado en Molina, por lo que solicitaron poder venir a pastar a Elche, petición que fue contestada favorablemente por los jurados de Elche ${ }^{69}$.

\section{LOS CONTINUOS ENFRENTAMIENTOS CON LOS GANADEROS VALENCIANOS}

Los privilegios concedidos a la ciudad de Valencia limitaban las posibilidades de explotación de los pastos, creando un agravio comparativo ante sus súbditos. El punto de partida era el amprius (también aparece con la grafía aemprius

67. A.M.O. Manual de Consells no 14, fol. 136 r y nº 15, fol. 98 r. 22-8-1417 y 27-4-1418, Orihuela.

68. A.M.E. Manual de Consells, 1. 20-4-1379, Elche.

69. A.M.E. Manual de Consells, 13. 30-12-1443, Elche. 
o emprius) o derecho que los vecinos de Valencia y su contribución tenían por concesión de Jaime I sobre los bienes comunales de todo el reino, incluidos los de tierras de villas y lugares de señores laicos o eclesiásticos. El derecho incluía la facultad de poder usar libremente de los pastos y caza, aguas y pesca, etc, sin que los señores pudieran oponerse a ello. La lucha por el control de los pastos se dirigía contra los ganados trashumantes, con el fin de que renunciaran a sus privilegios y pagaran por la utilización de las hierbas ajenas. Naturalmente, los valencianos no estaban dispuestos a renunciar a lo que consideraban su derecho, amparado por la legalidad vigente, los privilegios reales y los fueros, y los pleitos estuvieron a la orden del día durante estos siglos bajomedievales ${ }^{70}$.

Las noticias en la documentación medieval ilicitana se remontan a las actas del concejo más antiguas, y ya el 5 de noviembre de 1379 vemos a los ganaderos de Valencia instalados en el bovalar, que hacía pocos días que había sido amojonado. Se acordó que fueran algunos hombres donde estaba el ganado, cerca de la torre del Pla, dentro del bovalar, encontrándose con mucho ganado de Valencia. Les preguntaron a los mayorales por qué entraron en el bovalar, que estaba amojonado para que sólo lo utilizaran los vecinos. Los mayorales respondieron que tenían orden de los dueños de los ganados que los llevaran a pastar donde lo hicieran los ganados de los vecinos, y que no se irían de allí.

Los jurados, temerosos de que no hubiera suficientes pastos para todos («per la multitud dels bestiars de València no an que pasturar et se poria despoblar la vila»), acordaron enviar representantes a Orihuela y Alicante, donde tenían los mismos problemas, para hacer un frente defensivo común. En efecto, el 9 de este mes llegó una carta de Orihuela diciendo que ellos habían hecho sus bovalares para los vecinos y allí no entraban forasteros, una respuesta un tanto pretenciosa, aunque reflejo de lo que deseaban los jurados orcelitanos, pues hasta 1383 la villa de Orihuela no obtuvo de Pedro IV un privilegio por que se prohibía a los rebaños de Valencia y otros lugares entrar en los bovalares y lugares de pasto del término. Jaume Trilles, el mensajero de Elche en Orihuela, expuso a los jurados ilicitanos que los oriolanos habían hecho los bovalares más pequeños de lo que eran para los bueyes y animales de labranza, y que no se unirían a otros esfuerzos de fuera. Por su parte, Gil Gascó, jurado que estuvo en Alicante, hizo un relato de los daños causados por los rebaños de Valencia y de Xàtiva en el término y los embargos que ello generó, por lo que tuvieron que enviar mensajeros a Valencia para intentar resolver el asunto. Ante estas noticias el Consell de Elche acordó que ni los ganados forasteros ni los de la villa pudieran pastar en el bovalar, bajo

70. La aportación más reciente al tema es la de Graullera Sanz, V., «El territorio y la jurisdicción de la ciudad de Valencia. El tribunal dels «amprius», en XVII Congreso de Historia de la Corona de Aragón (Barcelona, 2000), Barcelona, 2003, vol. III, pp. 375-386. 
la pena de 60 sueldos, y que los ganados de los vecinos salieran del recinto en el plazo de tres días ${ }^{71}$

Unos días después, el 20 de noviembre de 1379, Jaume Trilles, lugarteniente del baile local, fue a Orihuela para tratar del tema de los ganados de Valencia que intentaban pastar en el bovalar. Le acompañaba Gil Gascó, jurado de Alicante, dado que esta problemática era común a todos los municipios de la gobernación, y, en general, de prácticamente todo el reino. La actitud de los ganaderos valencianos no siempre era insolente y de superioridad, sino que, según trasluce la documentación, también estaban dispuestos a respetar las dehesas y las ordenanzas locales. Así, los jurados de Elche embargaron de una cabaña ganadera de Valencia dos bestias porque el rebaño entró en el bovalar. El dueño, un tal En Berart, fue ese 20 de noviembre al Consell para resolver el tema y hablando «fort cortesment e omil» dijo a los jurados que ignoraba la prohibición y se comprometió a no entrar en el futuro en el recinto y a sufragar los daños ocasionados ${ }^{72}$.

Las medidas coercitivas de las autoridades municipales ilicitanas parece que, de momento, surtieron algún efecto positivo, pues en la reunión del Consell del 7 de diciembre de este año los jurados expusieron que, cuando los pastores valencianos supieron que el bovalar estaba reservado para los vecinos, se marcharon todos, salvo un tal Fontanars, que metió sus rebaños en los sembrados, en concreto en la huerta de Jiménez. Por ello fue multado y se le embargaron ocho ovejas, que fueron vendidas por 60 sueldos y 8 dineros. El día 9 de diciembre se le confiscaron dos bestias, un pollino negro y una burra pequeña, vendidos por 41 y 20 sueldos, respectivamente ${ }^{73}$. Lo cierto es que no todos los infractores eran de la ciudad de Valencia, pues el día 22 de diciembre fue multado Joan Morera, vecino de Elche, por meter su ganado en el bovalar, y durante todo el mes abundaron las denuncias a otros vecinos por dicha causa.

La realidad era que la presión ganadera de la ciudad de Valencia era tan fuerte que amenazaba con romper el equilibrio ecológico de estas dehesas, suponiendo una grave competencia para los modestos ganados locales. Esto se vio de forma muy clara en la discusión que sobre el tema se planteó el 11 de enero de 1380 en el Consell ilicitano y en la carta que se acordó enviar al infante Martín, señor de la villa. En ella los jurados se quejaban de «la gran multitud de bestiars o cabanyes de València» que había en el término y de su entrada en el bovalar que habían hecho «segons per fur nos és llegut fahedor». Pero la situación llegó a un punto en el que hubo que prohibir la entrada de los ganados en el bovalar

71. A.M.E. Manual de Consells, 1. 5 y 9-11-1379, Elche.

72. A.M.E. Manual de Consells, 1. 20-11-1379, Elche.

73. A.M.E. Manual de Consells, 1. 7-12-1379, Elche. Recoge también la noticia Ferrer i Mallol, Ma. T., Pastures i ramadería, p. 82. 
tanto a los ganados forasteros como a los de los vecinos. Los de Valencia querían entrar a pastar en el bovalar y en los «erbatges» de la señoría, tanto del infante como de su esposa. Se quejaban de la violenta y desafiante actitud del citado Fontanars, que por mucho que le multaran se negaba a sacar de allí su ganado. A ello se añadía la llegada de gran cantidad de vacas, que ponían en peligro el junco con el que los mudéjares confeccionaban sus esteras y la hierba con la que se hacia la sosa, productos de los que la señoría obtenía saneados ingresos, que amenazaban con perderse, además del consiguiente riesgo de despoblación, ya que, como era habitual, los vecinos dueños de ganado amenazaban con marcharse de la villa, y de todo ello la renta señorial se iba a resentir, por lo solicitaban al infante Martín que prohibiera la entraba en el bovalar de ganados de Valencia u otros lugares ${ }^{74}$.

A comienzos de 1380 los mensajeros que habían ido a Valencia a tratar el asunto del bovalar ya estaban en Elche, pues en la reunión del Consell habida el día 1 de febrero de 1380 explicaron a los jurados que en Valencia decían que «los boalars deven ésser preferits per a bèsties, e als moltons de carnicers», y si en ellos entraban los ganados de los vecinos, también tenían derecho a hacerlo los de Valencia. Los jurados decidieron que si se prohibía entrar el ganado de los vecinos lo mismo se haría con los de Valencia, siendo la pena a aplicar a los transgresores «la degolla», es decir el degüello de un cordero por cada rebaño ${ }^{75}$.

En años sucesivos la tensión con Valencia siguió candente y el 24 de marzo de 1382 los jurados ilicitanos se quejaban al infante Martín, su señor, por las continuas intromisiones de los ganados valencianos en las huertas de los moros y cristianos de la villa, no respetando los sembrados y tierras panificables, por lo que -alegaban- se corría el riesgo de despoblación, ya que las gentes en cuanto oían hablar de guerra se iban dejando indefensa la villa. Por ello solicitaban al infante que intentara que los ganados de Valencia no vinieran a Elche ${ }^{76}$.

En las Cortes de Valencia de 1403, reunidas por Martín I, se dieron las normas por las que se regirían en el futuro los bovalares: debían estar señalizados de tal manera que se distinguieran claramente por los ganaderos; su tamaño serían proporcional al de la villa donde se encontraban; los ciudadanos de Valencia no tendrían empriu de hierba; los que metieran sus ganados dentro del bovalar serían expulsados o castigados con la degüella de un animal si la infracción era de día y dos por la infracción durante la noche; si era ganado grueso (bestiar gros) pagarían 3 dineros por cabeza.

74. A.M.E. Manual de Consells, 1. fol. 136 r-v. 11-1-1380, Elche.

75. A.M.E. Manual de Consells, 1. 1-2-1380, Elche.

76. A.M.E. Manual de Consells, 1. 24-3-1382, Elche. 
En junio de 1417 la tensión con Valencia por culpa de los «amprius» había alcanzado tal grado que el Consell, reunido el 11 de junio, dispuso que Pere de Cornella, notario síndico de la villa, que iba a la capital del reino a tratar diversos asuntos del municipio, llevara consigo la protesta de las autoridades locales -0 un traslado autentificado de la misma- ante el monarca por causa de los citados «amprius» y otros temas.

Ese día se acordó también hacer una carta a Joan Bou, ciudadano de Valencia, por razón de los embargos que hacía a los vecinos de Valencia, con el fin de saber las razones de tal conducta y adoptar las medidas oportunas. Otra carta similar se hizo a Bertomeu Ferrer, ciudadano de Valencia, que también estaba embargando a los ilicitanos.

El 20 de junio en la reunión concejil, estando presentes el procurador y baile de la villa, se recibieron tres cartas enviadas por Joan Coromines, veguer de los jurados de Valencia, acordando que los gastos de la respuesta los pagaran el Consell de la villa y la aljama mudéjar. Se acordó consultar a los consellers de Barcelona, señora de la villa, en el asunto de la usurpación y jurisdicción que se atribuía el citado veguer, que había realizado marcas y embargos contra un vecino, solicitando al mismo tiempo la ayuda de Orihuela y Alicante, villas adonde se enviarían mensajeros. Los comisionados para ir a Orihuela fueron el ya conocido Bertomeu Ferri y Joan Cornellà, notario, ambos con gran experiencia en estos temas ganaderos. La respuesta de las autoridades locales de Elche a la actuación de Coromines fue apresarlo y meterlo en la cárcel. Para ir a Barcelona fue elegido el 22 de junio Pere Granyana, con documentación pertinente en la que se explicaban los sucesos acaecidos y la usurpación de la jurisdicción de la señoría de Barcelona por el veguer de Valencia. Para sus gastos se le daría una dieta de 9 sueldos diarios, a pagar entre la universidad de los cristianos y la aljama de los moros.

En la carta credencial de los jurados de Elche a sus colegas de Barcelona se aludía a la sentencia dada por Martín I en las Cortes de Valencia de 1403 acerca de los «amprius» de la ciudad de Valencia, según la cual los jurados de la capital tenían jurisdicción plena, en perjuicio de las villas del reino, pero los jurados de Elche alegaban que esta sentencia no afectaba a aquellos que no fueron citados a Cortes ni estuvieron presentes en ellas, como fue el caso de la señoría de Barcelona, que tampoco estuvo en su promulgación, ni Elche ni su síndico, por lo que la misma no debía afectar ni perjudicar a Barcelona ni a Elche o sus vecinos. Los jurados de Valencia se entrometieron en los «amprius» y ordenaron mediante cartas al Justicia de Elche que anulara los embargos hechos contra algunos pastores de Valencia a causa del daño causado por sus ganados en la huerta de la villa. La respuesta al envío del veguer Coromines y sus marcas contra vecinos de la villa fue, como hemos visto, meterlo preso en la cárcel local. Los jurados 
pedían a Granyena que revisara toda la documentación pertinente al tema con los abogados y que proveyeran con el rey, de tal forma que la jurisdicción de Elche y la de la señoría (Barcelona) no resultara perjudicada y en el futuro los ilicitanos no fueran molestados, dado que esta continua presión de la ciudad de Valencia estaba incitando a muchos vecinos a marcharse a Orihuela o a otros lugares de la gobernación («a estar e poblar en la vila d'Oriola e en altres parts d'aquesta governació»). Acompañaba también la petición para que los vecinos de Elche obtuvieran salvoconductos para no ser molestados en Valencia por el derecho de aduana, del que estaban francos, aunque algunos bailes generales pretendían cobrárselo $^{77}$.

En los días siguientes prosiguió la actividad municipal en torno al tema, y el día 25 de junio en la reunión del Consell, en presencia del baile Marc Escuder, Amet Albillení, lugarteniente del alcadí, Amet Citbo y Mahomat Milich, viejos de la aljama, y del consejero Axén Abenzacaria se comprometieron en nombre de la aljama a contribuir en la parte de los gastos que les correspondiera. El 7 de julio, el Consell, para evitar pleitos en el futuro, dispuso la liberación de Coromines.

El 27 de julio se presentó en el Consell de Elche la respuesta de las autoridades de Barcelona, señora de la villa, a las medidas adoptadas por los ilicitanos contra los ganados valencianos y la prisión del veguer. La señoría hizo que los abogados estudiaran la documentación remitida por Elche para ver cuáles eran los derechos de Barcelona y de los ilicitanos en este asunto, llegando a la conclusión de que serían los mensajeros de Valencia desplazados a Valencia, donde se encontraba el rey, los que presentarían dichas conclusiones al monarca para que éste decidiera. Como se ve, el asunto no estaba nada claro, Barcelona dudaba de las quejas de Elche, y nadie se atrevía a pronunciarse de una forma clara, por lo que le pasaban el problema al rey. A la vez devolvían a Pere Granyana, mensajero de Elche en Barcelona, para que no hiciera gastos inútiles y pedían a los jurados ilicitanos que, cuando se enteraran que los mensajeros de Barcelona estaban en Valencia, enviaran a alguien de la villa para trabajar juntos en el tema de los «amprius». Los nominados por el Consell para ir a Valencia fueron el ya citado Pere Granyana y Pere Cornellà, que conocían bien toda la problemática. Se les dieron credenciales para presentarse ante Alfonso V y se pedía al rey que los escuchara y ayudara. Seguía otra credencial para los mensajeros de Barcelona con los capítulos informativos transmitidos a los mensajeros, gracias a los cuales podemos conocer cuáles eran los motivos de fricción entre Elche y Valencia. Eran estos:

$1^{\circ}$ Los jurados de Valencia pidieron al Justicia de Elche que en diez días les enviara bienes de cualesquiera vecinos de Elche con el fin de reintegrar a

77. A. M.E. Manual de Consells, 3. 11, 21 y 22-6-1417. 
Joan Bou, mercader, y a Bertomeu Ferrer, vecinos de Valencia, las cantidades de dinero que se les debía en compensación de unos asnos que les fueron confiscados por el baile de Elche. El Justicia se negó a ello, alegando que iba contra los Furs del reino y la jurisdicción de la señoría.

$2^{\circ}$ Los jurados de Valencia requirieron al Justicia de Elche que en el plazo de diez días les remitiera bienes de los vecinos de la villa a fin de indemnizar a Bertomeu Ferrer, cabañero de Valencia, valorados en las 30 libras que éste decía que le habían causado de daños en su ganado algunos vecinos de Elche. La respuesta negativa del Justicia utilizaba los argumentos arriba citados.

$3^{\circ}$ Los jurados de Elche alegaban a su favor una sentencia sobre los «amprius» dada por Martín el Humano, según la cual los jurados de Valencia no podían proceder contra vecinos de Elche y vasallos de Barcelona, dado que dicha sentencia iba contra los fueros y privilegios del reino, a los que estaba acogida Elche. En segundo lugar porque, como ya dijeron en otra ocasión, cuando se dio la sentencia no se mencionó la ciudad de Barcelona, señora de Elche, por lo que dicha sentencia no afectaba a Barcelona ni a su jurisdicción en Elche, ya que la primera estaba en posesión del mero y mixto imperio sobre Elche. La sentencia se dio entre algunas universidades del reino, entre las que no se encontraba Elche. Cuando en la villa se conoció la misma, los jurados enviaron sus mensajeros al rey Martín para protestar por la misma, y, según alegaban, el rey respetó los derechos de Elche y de sus vecinos.

$4^{\circ}$ Exponían los jurados de Elche que un tal Joan Coromines (o Colomines), vecino de Elche, dijo ser veguer de los jurados de Valencia y compareció ante el lugarteniente del Justicia de Elche, diciendo que estaba en la villa para embargar bienes de los ilicitanos y restituir lo debido a Joan Bou, de Valencia, por causa de la degüella que se le hizo en el pasado, valorados en 12 libras. Se le expuso que Barcelona era la señora de Elche y que tenía su propia jurisdicción, por lo que Valencia no podía intervenir ni llevar a cabo dicho embargo. Coromines había tomado una espada de casa de Sancho de Lorca, zapatero, razón por la cual el Justicia lo encarceló.

$5^{\circ}$ Los jurados de Elche reconocen que hicieron degüella en el ganado de Bou, pero insisten en que los jurados valencianos no tenían potestad para actuar, según «fur e rahó», ni perjudicar a la ciudad de Barcelona ni a elche y sus particulares

$6^{\circ}$ Los munícipes ilicitanos consideraban que Coromines era digno de castigo, pues «follament» no respetó la jurisdicción de Barcelona, aunque luego los oficiales de Barcelona en Elche lo liberaron y le dejaron volver a Valencia. No contentos con ello, los jurados de Valencia tomaron re- 
presalias contra Antoni Ferri, de Elche, al que embargaron sus ganados en Bocairent y a él lo encarcelaron en Valencia. Los jurados de Valencia apresaron también en Biar a dos moros de Crevillent con tres bestias que llevaban cargadas de esteras de junco, llevándolos presos a Valencia. Los ilicitanos piden a la señoría de Barcelona que los defienda, recupere lo embargado y se les resarza con los daños y perjuicios ${ }^{78}$.

El correo entre Elche y Barcelona empleaba nueve días en recorrer el trayecto, y la respuesta de los consellers barceloneses se produjo a vuelta de correo, el 6 de agosto, llegando a Elche el día 15 de ese mes, en que fue leída en el Consell. En ella se dice que la ciudad de Barcelona, para evitar mayores inconvenientes, decidió escribir a los jurados de Valencia para que paralizaran el tema hasta que llegaran sus mensajeros y juntas pudieran las partes discutir el tema sin perjudicar a nadie. Les pedían, entre tanto, a los jurados de Elche que no procedieran contra los intereses de Valencia y de sus ciudadanos.

El 1 de septiembre llegó a Elche otra carta fechada el 26 de agosto y enviada desde Valencia por el mensajero de la villa, Pere Granyana, en la que cuenta que entró en la capital «ans del seny del ladre»y pronto se enteró de que los mensajeros de Barcelona no habían llegado aún, por lo que, temeroso de los jurados de Valencia, se ocultó en un lugar seguro. El jueves llegaron los mensajeros barceloneses, Berenguer Dezcortell y Galcerà Cargó, a los que Valencia tributó un gran recibimiento, acudiendo incluso gente a caballo. Al amanecer Granyana fue a su posada, les hizo reverencia y les presentó su credencial, informándoles de los acontecimientos. Los barceloneses procuraron tranquilizarlo, diciendo que los jurados de Valencia harían cuanto ellos les pidieran, dado que en casos contrarios Barcelona hacía lo mismo con los de Valencia. Les daba también noticia del apresamiento hecho en Valencia el sábado de un mozo y de Ramonet «lo çabater», vecinos de Elche. La inquietud de Granyana fue en aumento porque, al atardecer, vio que su mozo no había llegado a casa a cenar, por lo que pensó que lo habían detenido. Parece que la instigadora de todo era una mujer, una tal $\mathrm{Na}$ Guillamona, por lo que Granyana, temeroso, se cambió de residencia y se marchó a un hostal fuera de la ciudad para que no lo encontraran. Cuenta que luego alguien le ayudó a esconderse de los jurados y de la mujer, hasta que el lunes fue a preguntar a los de Barcelona si habían hablado ya con los jurados, pero la visita del ilicitano no fue del agrado de los mensajeros de la señoría, que sabía que lo buscaban los jurados. Éstos dijeron que preferían como mensajeros a Pere Ferràndez de Mesa y a él, pero el acuerdo sobre los sucesos tratados seguía pendiente. Los de Barcelona le pidieron que no fuera a verlos hasta que le avisa-

78. A. M.E. Manual de Consells, 3. 25-7-1417, Elche. 
ran, cosa que hicieron el viernes siguiente. La respuesta al mensajero de Elche fue que los jurados de Valencia querían tomarse este asunto con calma, en honor a dichos mensajeros, y pidieron a Elche que enviara dos o tres mensajeros para informarse de los hechos.

Una nueva carta de Valencia, fechada el 27 de agosto, llegó al Consell de Elche y en ella se decía que todos los encarcelados estaban ya en la calle, y que Alí Hamiz, moro de Valencia, dijo que iban a liberar a los moros de Crevillent, saliendo fiadores él mismo y un mercader cristiano. El Consell ilicitano acordó escribir a los mensajeros de Barcelona y enviar como representante de la villa al notario Pere Bataller. En la carta, los jurados ilicitanos manifestaban su sorpresa a los barceloneses por la respuesta dada por los jurados de Valencia y les recordaban la carta de los consellers de Barcelona del 15 de julio, en la que decían que los acuerdos entre el rey, Barcelona y Valencia debían ponerlos en marcha los citados mensajeros, quejándose de que si no se tomaban las medidas adecuadas la villa se despoblaría y con ello disminuirían las rentas de Barcelona. En esta especie de chantaje lacrimógeno decían que ya no enviarían otro mensajero, aparte de Granyana, y mostraban su disgusto por no haberle apoyado ante el acoso de los jurados de Valencia, tal como una señoría debía proteger a sus vasallos. Es más, podían haber acudido ante el rey, que entonces estaba en Valencia, y protestar a los jurados de Valencia por las medidas adoptadas contra los vecinos de Elche que estaban en la capital. Los jurados de Elche en su misiva querían dejar claro que ellos eran más generosos, pues a Elche, decían, acuden muchos valencianos contra los que no se han tomado represalias, como podían haber hecho. En definitiva, les instaban a resolver este asunto sin perjuicio para los fueros y privilegios de Elche. En otra carta enviada por Granyana a los jurados de Elche les pedía que solicitaran del monarca un salvoconducto general para que los vecinos de la villa pudieran ir, estar y regresar por el reino sin ser víctimas de los abusos de los jurados de Valencia. Lo cierto es que, como confesaban los jurados ilicitanos a los mensajeros de Barcelona en su carta del 22 de octubre, los vecinos de Elche no se atrevían a ir a Valencia por miedo a ser encarcelados o embargados.

El pleito con Valencia no se resolvió y el 13 de mayo de 1418 en una carta de los jurados de Elche a los consellers de Barcelona el motivo de la disputa con Valencia era la pena que se debía aplicar a los ganados transgresores de los vedados. Los de Elche querían que se pagaran los 60 sueldos estipulados, en tanto que los de Valencia alegaban que no estaban obligados a dicha pena sino a la de la degüella, tal como se declaraba en los capítulos de la sentencia de los «amprius» dada por Martín I entre Valencia y otras universidades. Según la misma cada vez que los valencianos metieran su ganado en la huerta o en el bovalar se haría degüella de una res si era de día, y de dos si era de noche. Los oficiales 
ilicitanos aludían a que la pena de los 60 sueldos era para todos, sin excepción, pero ante la duda pedían consejo a Barcelona y que les aclarara si habían de aplicar la degüella en los ganados de los valencianos y si ello suponía reconocer la jurisdicción de los jurados de Valencia en Elche, así como si podían usar ambas penas: la degüella y las multas ${ }^{79}$.

Otro grave incidente se produjo en la primavera del año 1429. En la reunión del Consell del 18 de abril Andreu Fira, mensajero de Elche, expuso a los asistentes que el día 1 de ese mes él y el procurador de la villa fueron a la ciudad de Valencia, y al día siguiente, que era sábado, hablaron con micer de Santa Cilia, el abogado del Consell ilicitano, representante de sus intereses en Elche, sobre la prisión hecha por los jurados de Valencia a Francesc Medina, notario, y Berenguer de Quexans, Gabriel de Quexans, labradores, Vidal Morera y Bertomeu Bordes, todos ellos vecinos de Elche. La prisión se hizo a instancia de varios ganaderos (cabanyers) de la ciudad que tenían quejas contra la villa de Elche, por un pastor de Valencia que allí fue herido y por el ganado que había perdido a consecuencia de ello. Se quejaban, además, porque en Elche les hicieron algunas degüellas de ganado, mientras que otro pastor decía que le habían pegado con una vara de lanza. Los ilicitanos acudieron luego a la sala del Consell de Valencia, donde estaban reunidas las autoridades locales, presentando sus credenciales y solicitando explicaciones por aquella prisión, que consideraban injusta. Los jurados de Valencia, por su parte, dijeron que no los liberarían hasta que no se hubieran satisfecho los daños causados.

Ese lunes los mensajeros de Elche siguieron insistiendo en su reivindicación, en tanto que los valencianos se mantuvieron firmes en su postura, por lo que Santa Cilia dejó en prenda un anillo de plata con unos rubíes, valorado en 200 libras, como prenda por dichos daños y sus gastos. Los ilicitanos liberados se comprometieron a no pasar a Ultramar ni salir fuera del reino, así como a comparecer ante los jurados de Valencia en el plazo de veinte días, cuando fueran requeridos.

El Consell de Elche aprobó la gestión realizada y dio las gracias al abogado. Santa Cilia, por su parte, les escribió desde Valencia el 13 de abril -la carta tardó cinco días en llegar desde Valencia-y les narró la venta del anillo por 200 libras, suma en que fueron tasadas las quejas de los jurados valencianos. A su vez, pedía al Consell que el día 20 estuviera en Valencia el síndico de la villa con dicha cantidad de dinero para resolver el asunto. A tal fin se acordó enviar a Pere Granyana con las 200 libras $^{80}$.

79. A. M.E. Manual de Consells, 3. 13-5-1418, Elche.

80. A.M.E. Manual de Consells, 6. 18-4-1429, Elche. 
Otro incidente del que tenemos noticias se produjo en la primavera del año 1434, y lo conocemos por la carta remitida el 12 de mayo por los jurados de Valencia a sus colegas ilicitanos, en la que se hacían eco de las quejas presentadas por Andreu Ferrer, labrador y ganadero, que hacía tres meses y medio o cuatro, cuando tenía su ganado de 1.150 cabezas en el término de Elche, en dos rebaños, «sens fer mal ni dan, segons lié s lícit e permés en virtu dels dits amprius, franqueses e libertats», hombres de Elche le robaron dos carneros, valiendo 13 sueldos cada uno, a lo que se añadieron otros borregos con sus crías, por lo que los jurados solicitaban que se procediera a embargar bienes de los culpables y a resarcir económicamente las pérdidas del ganadero valenciano. Los jurados de Elche ordenaron a Pere Bataller, notario y asesor del Justicia, que fuera a ver a Felip d'Ampuries, vecino de Alicante y abogado del Consell, para mostrarle dicha reclamación, llevando también los libros de las degüellas, y que apliquen la justicia correspondiente ${ }^{81}$.

Los problemas siguieron y el 31 de agosto de 1440 los jurados de Elche escribieron una carta al Justicia de Valencia sobre la reclamación de las degüellas, diciendo que la jurisdicción que tenía el juez de las degüellas, que se le concedió en el pasado, había cesado por ser una concesión temporal hasta las siguientes Cortes, y el tiempo de éstas ya había pasado sin que hubiera habido una prórroga, máxime cuando Elche no fue convocada a las mismas. El 23 de septiembre se presentó ante el Consell un veguer de la ciudad de Valencia con cartas de los jurados de la capital, en las que se requería a los ilicitanos a que en el plazo de diez días abonaran las importantes sumas de dinero reclamadas por los ganaderos de Valencia, por causa de los dados ocasionados por la degüella en sus rebaños por gentes de Elche.

Elche siempre tuvo una representación del Consell en la capital del reino, dados estos pleitos, por lo que, oída la queja, acordó enviar una carta a Pere Bataller, notario y procurador de la villa en Valencia, o en su ausencia a Joan Mas, notario y síndico de Elche, para que la llevaran a micer Gabriel de Santa Cilia, el abogado de la villa. En ella le narraban lo sucedido y le remitían las actas de la degüella que habían podido encontrar en poder de los notarios del año pasado y del presente. Si Bataller se encontraba con Mas en el camino, tenía orden de regresar a Valencia para presentar dicha instancia, remitiéndole tres volúmenes de traslados de los actos de las degüellas, que, por desgracia, se han perdido. Este dato es revelador de la trascendencia que en Elche tenía la presencia de los ganaderos valencianos y de las frecuentes infracciones cometidas, siempre desde el punto de vista ilicitano.

81. A.M.E. Manual de Consells, 8, 30-5-1434, Elche. 
El pleito por las degüellas planteado por los ganaderos de Valencia contra Elche seguía en junio de 1442, y el 29 de este mes los jurados ilicitanos acordaron enviar con credenciales a la capital a Pere Codines, alias Sepulcre, para entrevistarse con el abogado de la villa, Santa Cilia, a fin de intentar resolver dicho contencioso, haciendo lo mismo con los ganaderos, procurando llegar a un acuerdo, tras haberlo consultado con el Consell. A tal fin iría provisto de una serie de capítulos acordados por la institución municipal ${ }^{82}$. Por una carta posterior, del 14 de septiembre, sabemos que los ganaderos valencianos reclamaban una indemnización de 15.000 sueldos. Para lograr el acuerdo éstos nombraron una comisión de cuatro personas en representación de los perjudicados, quienes elegirían un síndico, igual que tenía Elche, en tanto que el notario Pere Bataller, actuaba como síndico de la villa de Elche. El 7 de octubre Bataller presentó el informe de su gestión al Consell de la villa, hecha de forma conjunta con Gabriel de Santa Cilia, el abogado de la villa, y de las reuniones mantenidas con los ganaderos.

A comienzos del año 1480, pero con raíces anteriores, volvió a recrudecerse la tensión entre Elche y Valencia, como se desprende de la misiva enviada por los jurados de Valencia a los de Elche y Crevillent, ante la queja presentada por los ganaderos valencianos diciendo que en ambas localidades se habían lanzado pregones ordenando a sus vecinos que no apoyaran ni dieran ayuda a los de Valencia que tenían sus ganados en dichos términos, no acogieran a mayorales ni pastores en sus casas, ni a los hatos, así como tampoco les vendieran vino, pan, aceite u otros alimentos; ni que los molineros no les molieran el trigo, bajo la pena de mil florines. Expusieron también al Consell de la capital la ampliación del bovalar ilicitano y cómo hacían degüellas indebidamente, contra fueros y privilegios en los herbajes y amprius de que gozaban los valencianos. Ambos lugares eran de la reina Isabel, por lo que les escribían pidiendo que revocaran dichas disposiciones contra los ganaderos de Valencia, pues de lo contrario procederían contra ellos «com a jutges reintegradors de les franqueses e libertats de la ciutat», de acuerdo con la sentencia de los «amprius», fueros y privilegios del reino. De momento no avisarían a los reyes de la situación planteada, pero de no revocar tales órdenes procederían a actuar sin paciencia. A su vez recordaban a los jurados de Elche la sentencia de la reina Juana, dada en Valencia el 7 de mayo de 1465 referente a asuntos similares hechos en aquellas fechas por ellos o sus antecesores en el cargo, en concreto sobre ciertas dehesas que pretendía proteger contra los ganados valencianos. En su sentencia, la reina dispuso que Elche y Crevillent debían sujetarse en todas las normas que dictaran a lo dispuesto en los

82. A.M.E. Manual de Consells, 12. 29-6-1442, Elche. 
Furs, a la ley universal que las demás villas, castillos y lugares del reino tenían con respecto a los ciudadanos de Valencia ${ }^{83}$.

A principios del año 1483 los ganaderos de Valencia recurrieron a los jurados de la ciudad, exponiendo que las autoridades locales de Elche y de Crevillent habían dado pregones ordenando que nadie apoyara a los de Valencia que tenían ganados en los términos de ambas localidades, ni acogieran a los mayorales y pastores en sus casas, ni a los hatos de ganado, ni les vendieran pan, vino, aceite u otros alimentos; se prohibía a los molineros molerles trigo, bajo la pena de mil florines. Se quejaban también de la ampliación del bovalar ilicitano, lo que les resultaba muy dañoso, a la vez que hacían degüellas de forma indebida, en contra de los fueros y privilegios referentes a los herbajes y «emprius» de que disfrutaban los ganaderos de la capital. Como ambos lugares pertenecían a la reina -doña Isabel-, los jurados de Valencia escribieron a sus colegas de Elche y Crevillent el 7 de marzo, pidiéndoles que revocaran dichas medidas contra los ganaderos de la ciudad, ya que de lo contrario procederían contra ellos «com a jutges reintegradors de les franqueses e libertats de la ciutat», de acuerdo con la sentencia de los amprius, fueros y privilegios del reino. De momento no pensaban avisar a los monarcas, pero en el caso de que no revocaran dichas medidas, procederían de forma inmediata contra ellos. Les recordaban la sentencia de la reina Juana, dada en Valencia el 7 de mayo de 1465, referente a otro asunto de la misma índole llevado a cabo por los de Elche y Crevillent, en concreto sobre ciertas dehesas, que pretendían proteger contra los ganados valencianos. La reina, en su sentencia dijo que Elche y Crevillent debían sujetarse a todas las normas forales, a la ley universal que tenían las villas, castillos y lugares del reino, en todo lo referente a los ciudadanos de Valencia ${ }^{84}$.

A finales de los años ochenta el Consell de Elche mantuvo una posición unitaria, junto con los de Alicante y Orihuela, contra las invasiones de sus cultivos por los ganados valencianos. En 1488 Elche solicitó la intervención real en el pleito, considerándose agraviada porque el veguer de Valencia estuvo en Elche y quiso usar su jurisdicción. Tanto Fernando II como Gutierre de Cárdenas dilataron la respuesta alegando que era Semana Santa y que, pasada ésta, vendría luego a Elche y Orihuela ${ }^{85}$.

El invierno de 1488-1489 los mensajeros de las tres localidades de la gobernación oriolana se encontraban en Medina del Campo, tras un viaje y una estancia de cincuenta y cinco días, que no debió de ser especialmente cómodo,

83. A.M.V. Lletres Misives, g3-29, fol. 203 r-v. 7-3-1480, Valencia.

84. A.M.V. Lletres Misives, g3-29, fol. 203 r-v.

85. A.M.E. Manual de Consells, 18, fol. 53 v. 8-4-1488, Elche. 
pues en el pago de sus salarios, hecho en marzo de 1489, se alude a los «molts treballs, de moltes aygües que haut en lo camì», así como a las «moltes neus» que cayeron en Medina del Campo, donde estaba el monarca ${ }^{86}$. El 7 de marzo de 1489 Fernando II de Aragón dio sentencia en Medina del Campo en el pleito mantenido por Elche y Crevillent contra Valencia por pretender Valencia tener privilegios de disfrute de pastos, además de la sentencia de Martín I de estar en pacífica posesión de poder pastar francos sus ganados en dichas localidades. Elche y Crevillent alegaban disfrutar del mismo privilegio que Orihuela, que estaba exenta de la pretensión de Valencia. La sentencia dispuso que Valencia nombrara a una persona notable y de buena fama, y Elche y Crevillent otra, y ambas vieran y reconocieran las redondas antiguas y las amojonaran para que en ellas no entrara ganado de Valencia ni de otras partes, bajo la pena de 30 sueldos si era de día y 60 si era de noche, pena más favorable que cuando se trataba de otros ganados, que era de una cabeza de ganado de día y dos si era de noche, similares a los que encontramos en otras zonas del reino, como es el caso de la actual provincia de Castellón ${ }^{87}$. Estas penas eran para la corte del Justicia de la villa, así como la tercera parte de la pena por invadir la huerta, quedando salvaguardadas las dehesas del señor. Si no se ponían de acuerdo en dicha delimitación, el rey nombraría como tercer al doctor Francesc d'Artés, y su acuerdo se redactaría ante notario, siendo remitido al vicecanciller para que fuera respetado. Se dispuso también que los sembrados de la ciudad y villa fueran vedados a los ganados de Valencia y otros lugares, con las mismas penas, las dos partes para el dueño de la heredad y la otra para la corte de la ciudad y villa y pago del daño hecho, en cuyo caso el mayoral o el dueño del ganado nombraría un apreciador y la parte afectada otro, y si no se ponían de acuerdo, el Justicia de Elche nombraría un tercero que no fuera sospechoso a las partes. La ciudad y la villa darían camino recto para que pudieran pasar los ganados, así como abrevadores para beber el ganado, con el conocimiento de los citados expertos, o de un tercero si no había acuerdo ${ }^{88}$.

86. A.M.E. Manual de Consells, 19. 7-3-1489. El Consell añadió un sueldo diario al salario estipulado a los mensajeros, Berenguer d'Alvado y Jaume Martí.

87. Díaz Manteca, E., Establiments de la vila de Vilafamés, Castellón, 1982; Doñate Sebastiá, J. Mª., «Ordinacions i estatuts de Villarreal», en Datos para la Historia de Villarreal, IV, Villarreal, 1977, p. 651; GARCIA Edo, V., Ordenanzas municipales de Benicarló a comienzos del siglo XV, Benicarló, 1978; Mateu Llopis, F., Establiments de la vila d eEl Boixar, Castellón, 1969; Revest Corzo, L., Llibre de Ordinacions de la Vila de Castelló, Castellón, 1957; SÁnChez Adell, J., «Establiments de Morella y sus aldeas, de 1370», en Boletín de la Sociedad Castellonense de Cultura XXX (1954), pp. 249-260; SÁnChez Adell, J., «Algunos aspectos de la práctica ganadera medieval en tierras castellonenses», en Estudis Castellonencs, 5, 1992-93, Pp. 349-394.

88. Nieto FernándeZ, A., Orihuela en sus documentos. II Economía y sociedad, pp. 101-102. 
En la sesión municipal del 15 de noviembre de 1489 el procurador de Cárdenas -que a la sazón estaba en Baeza, en la guerra de Granada-volvió a la carga y planteó ante los jurados y consejeros diversas reivindicaciones, entre ellos las quejas de los agricultores contra los ganados («clams dels bestiars»). Cárdenas escribió a la demanda de los jurados el 30 de noviembre en tono conciliador, diciendo que se hiciera de la forma que siempre se hizo. La falta de documentación posterior impide seguir el enfrentamiento por el beneficio económico que se derivaba de las penas de los ganados con detalle, pero parece que el Consell supo captarse la voluntad del monarca aragonés con alguna provisión favorable de fines de 1490 o comienzos de 1491 -que desconocemos-, como se desprende del enfado de Cárdenas en una misiva dirigida en mayo de 1491 al Consell. En ella se lamenta de los mensajeros de la villa en la corte que «fueron talles e tan buenos que, sin más de consultar sobre ello, ganaron la provesión que quizieron, no haziendo quenta en las penas como antiguamente stava senyalado; las penas todas para quien ellos quizieron, en prejudicio mio, no curando de mirar la merced e beneficio que de mi havien recebido---hy certo yo he ovido dello tanto enogo... $\rangle^{89}$. Cárdenas recordaba que en las penas tradicionalmente se habían hecho tres partes, una para el señor, otra para el dueño de la heredad y la tercera para el acusador.

El triunfo del Consell ilicitano fue efímero, pues Cárdenas, como era de esperar, no se resignó y su actitud no fue sólo de lamento, sino que pasó a la ofensiva, obteniendo una provisión real por la que se volvía a las condiciones de 1489, que el Consell no tuvo más remedio que acatar.

\section{LA PROTECCIÓN DE LA HUERTA. GUARDAS Y MULTAS SOBRE EL GANADO}

Una preocupación para todas las autoridades municipales fue la protección de la huerta y de los sembrados de las entradas del ganado, y los mismos Furs del reino se hicieron eco de tal inquietud, centrándose en la huerta de Valencia: «Negú no tingue cabana de bestiar d'ovelles ne de vaques ne d'altres bèsties, dintre la orta o alqueries de la orta de la ciutat, sinó d'aquels bous o d'aquelles bèsties que hauran a obs a laurar, les quals tingue en sa pròpia heretat $\rangle^{90}$. Pero el problema era general en todas las poblaciones, por lo que similares fueron las medidas adoptadas por autoridades y particulares, centradas en la prohibición de que entrara el ganado en las propiedades particulares. Allí donde se conservan

89. A.M.E. Manual de Consells, 19, fol. 86 r-87 r. 15-5-1491, Elche.

90. Colom, G., - García, A., Furs de València, Barcelona, ed. Barcino, 1980-1995. 6 vols. Vol. I, Libre I, Rúbrica II, Fur IV, p. 114. 
las ordenanzas municipales, nunca faltan estas disposiciones, y Elche no fue una excepción. Así, por ejemplo, el 25 de mayo de 1435 los jurados prohibieron que nadie atara bestias en los álamos, higueras, olivos y otros árboles que han sido plantados en las eras de la villa, junto a la acequia que pasa por dichas eras o plaza de Santa Llúcia, bajo la pena de diez sueldos.

El objetivo de las autoridades era proteger las tierras cultivadas, por lo que se prohibía que el ganado entrara en «los plantats», las viñas, incluídas las calificadas como «exuberants», es decir las que estaban en plena producción, el regadío y el secano susceptible de recibir lluvia, y en la ordenanza del 24 de febrero de 1382 se autorizaba que pacieran los ganados entre el 1 de noviembre y el 1 de febrero, declarando los viñedos abiertos. En el resto de tierras podían pacer mientras que haya fruto, si hubiera yerba y fuera del tiempo de riego o de lluvia, sin estar labrado. Si el campo plantado estaba labrado y cultivado, el ganado que entrase pagaría la multa habitual, igual que si lo hhiciera cuando hay fruto. Se prohibía entrar en los majuelos pequeños, de uno a tres años, bajo la pena de 10 sueldos, a repartir en tres tercios para el acusador, el señor de la propiedad y el Justicia $^{91}$. Dice así la ordenanza:

«Item, que no entren en los plantats ni en les vinyes, ne en regats, ne en guarets que sien tempiroses de pluja, ne en vinyes exuberants, emperò que a les vinyes pusquen entrar a pasturar del primer dia de noembre tro al primer dia de febrer, per ço que com en aquell temps no y poden fer dan encara que sia exubert. E en los altres plantats pusquen pasturar mentres fruyt no y aja, si serà erbós e exut de lo temps del regat o de pluja que d'aquells temps no serà llaurat. E si lo plantat serà llaurat e conreat e y entraren a pasturar, que sien tenguts a la dita pena, encara que no y aja fruyt. Emperò que mentres lo fruyt sie e y entraran a pasturar tota vegada sien tenguts a la dita pena mentres fruyt y aurà.

Item, que no entren a pasturar en mallolets de un ayn tro en tres ayns en tot l'ayn, sots la dita pena de deu sous, a la qual pena de deu sous si contra les dites desús dites faran per cascuna vegada sien tenguts, pagadors lo terç al acusador e lo terç al senyor de la proprietat e lo terç als guardians per fer la execució esmenada de la tala o dan sy fruyt hauran».

En 1420 los jurados de la villa consideraron que lo mejor para proteger las tierras era que el ganado de los vecinos fuera agrupado, por eso el 6 de septiembre dispuso que de todos los «pegullars» de los ganados locales se hiciera un rebaño, que fuera por la huerta paciendo por los lugares especificados en los

91. A.M.E. Manual de Consells, 1, fol. 227 r-228 r. 24-2-1382, Elche. Hinojosa Montalvo, J., Textos para la Historia de Alicante, doc. $\mathrm{n}^{\circ}$ 93, p. 239. 
capítulos del seguro de la huerta, y que dicho ganado se destinara al aprovisionamiento cárnico de Elche ${ }^{92}$.

La protección de las acequias, de frágiles estructuras, frente a intromisiones ganaderas era constante. El 11 de junio de 1441 el Consell dispuso que nadie pasara con su ganado por los cajeros de la acequia del Molinar ni en «les testeres» que estaban encima de dicha acequia, en un radio de acción que iba desde el molino Nuevo hasta el azud o almeyda, donde arrancaba dicha acequia de la Acequia Major, bajo la pena de 20 sueldos, un tercio al acusador, otro al Justicia y el restante a los jurados para limpieza de dicha acequia ${ }^{93}$.

Había ocasiones en las que resultaba muy difícil o imposible saber quién era el causante de los daños en los sembrados, por lo que el 26 de octubre de 1442 el Consell, para proteger los trigos olivos y las viñas de los destrozos del ganado y no se podía averiguar el culpable, decidió que cualquier persona perjudicada por dicha tala pudiera apoderarse del ganado que encontrara más próximo, y si no lo encontraban que obtuvieran un juramento de los pastores del término de que ellos no habían sido. En este caso todos los dueños de ganado de la villa correrían con la indemnización y gastos habidos, siempre que en el término no hubieran ganados forasteros ${ }^{94}$.

En ocasiones, las autoridades hacían excepciones en las entradas del ganado en los campos, y el 4 de marzo de 1487 se autorizó al ganado del asegurador de la carne de la villa a que pudiera pacer por las viñas, desde San Miguel hasta el 31 de enero, es decir el periodo en el que las cepas están inactivas, sin pagar por ello pena alguna, pero si lo hiciera pasada dicha fecha abonaría una multa de 10 sueldos y los daños causados. Se le prohibía entrar durante todo el año en los majuelos pequeños, que sólo tenían uno o dos años, ni en las alfalfas, azafranares, trigos y olivares susceptibles de ser regados o recibir la lluvia ${ }^{95}$.

Una parte de los ingresos de los arrendadores de los pastos procedían de las penas que recaudaban sobre los rebaños que incumplían las condiciones de los contratos de herbaje.

La vigilancia de la huerta y del bovalar era arrendada anualmente, y en 1370, por ejemplo, lo fue por la suma de 250 sueldos, pagaderos de inmediato 200 sueldos y los 50 restantes cuando finalizara el año. Para vigilar el término ilicitano los arrendadores se ayudaban de guardas rurales, siendo abonado su salario por el arrendador. Su función terminaba una vez concluía el contrato de arren-

92. A.M.E. Manual de Consells, 7, fol. 120 v-121 r. 6-9-1430, Elche.

93. A.M.E. Manual de Consells, 12. 11-6-1441, Elche.

94. A.M.E. Manual de Consells, 12. 26-10-1442, Elche.

95. A.M.E. Manual de Consells, 18. 4-3-1487, Elche. 
damiento. Visitaban diariamente el término municipal para comprobar que los ganaderos tenían la correspondiente autorización para pacer, cobraban los derechos de herbaje y si había infracciones imponían las multas y confiscaciones establecidas en los capítulos. La vigilancia de los guardias debía extremarse tras el toque de queda para evitar acciones incontroladas, amparadas por la oscuridad.

La pena más frecuente era confiscar un cierto número de reses por rebaño, que luego se vendían. Su importe se repartía entre el guarda, el arrendador y el dueño de los pastos. En caso extremo se procedía a degollar algún animal, para que sirviera como ejemplo. Otras veces la multa era en dinero en metálico. Todas las penas se duplicaban si la infracción era cometida durante la noche.

Un asunto del que estamos muy mal informados es el referente al robo de ganado, que debió ser más frecuente de lo que pensamos, aunque pocas veces aparece en la documentación. El tema ocupó un lugar preferente en las discusiones habidas en el seno del Consell de la villa el 19 de febrero de 1451, a raíz de la prisión por el Justicia de Joan de Quart, vecino, que fue acusado de haber robado hacía unos días en el término de Elche ciertos carneros. La prisión se hizo por orden del procurador y a través de las actas vemos que Quart reconoció ser el autor del robo, como así afirmaron haber escuchado diversos testigos, pero lo que interesa destacar es que el Consell se convirtió en acusación particular del caso «per ço que los mals sien castigats», ya que como dijo en público el notario Joan de Malla «en la dita vila se fan moles furts e negú d'aquells no se'n fa càstich, per ço com no-y ha acusació de part privada».

Parece, pues, que por aquellas fechas los delincuentes actuaban con bastante impunidad en Elche y su término, despoblado y difícil de controlar. A ello se unía la tensión bélica en el vecino reino de Murcia, que repercutía de forma muy intensa en toda la frontera meridional valenciana. De hecho, cuando el notario Pere Bataller, uno de los prohombres de la villa y de los que más entendían en cuestiones ganaderas, marchó a Orihuela a entrevistarse con el lugarteniente del gobernador, se encontró con que dos hombres le requirieron para que devolviera 350 carneros, que escuderos y hombres del noble mosén Diego Fajardo se habían apoderado en el término de Elche y tenían escondidos en el de Abanilla, lugar del señorío de Fajardo. La postura del Consell fue de no inmiscuirse en la querella, con el fin de evitar conflictos con el poderoso Fajadro, y dejar que se resuelva entre los interesados, pero con el fin de salvar las apariencias dispuso que «lo dit Justicia semblant forma de Furs e privilegis del present regne faca justícia en lo dit fet》.

En la reunión del Consell hubo posturas a favor y en contra de la intervención en este tema del robo de ganado y de Fajardo, y algunos como Francesc d'Uverna, dijeron que «ha gran plaer que los ladres sien castigats, segons forma de Furs e privilegis del regne», pero una opinión general era que en el caso de 
que el Consell hubiera de intervenir debía hacerlo el Consell General y no el especial u ordinario ${ }^{96}$.

\section{LA FISCALIDAD EN TORNO A LA GANADERÍA}

El herbazgo era el canon que se cobraba por la cesión del uso de la hierba para pasto del ganado por parte de los propietarios a los pastores, pero también se utilizaba en el sentido fiscal de sinónimo de «montazgo». En la primera mitad del siglo XIV se utilizó con más frecuencia el término «herbatge», pero en la segunda se impuso el de «carneratge» o «montalgo» (o las variantes de «montazgo», «muntalgo», «muntagdo»), que en 1376 las fuentes de la bailía general de Orihuela definen como el derecho que «se acostuma arrendar e cullir dels bestiars no havent franquea del dit dret, erbejants en qualsevol tèrmens dels dits lochs» de la citada bailía de Orihuela ${ }^{97}$. En ocasiones herbaje y carneraje aparecen juntos, unas veces como sinónimos y otras como impuestos diferentes.

Este impuesto del herbazgo, montazgo o carneraje era el más importante de todos, el que más rendimientos producía, sobre todo a nivel de la bailía general «dellà Sexona», pero también en el caso del señorío de Elche, y era de seis carneros por cada millar de ovejas para los ganados de Valencia y Aragón, en tanto que los del reino de Castilla abonaban el doble, doce cabezas por millar.

A partir de la conquista, la Corona fue cediendo el usufructo de las hierbas a favor de las villas reales, como hizo en 1252 con Alicante y años más tarde, quizá en 1265, con Orihuela. Sabemos también que en 1308 Jaime II concedió al arraez de Crevillent, en prueba de su fidelidad al monarca, el herbaje de Crevillent, Albatera y $\mathrm{Cox}^{98}$. Los señores gozaron de prerrogativas similares en sus señoríos, como es el caso de Elche en 1377, durante el señorío del infante Martín, que es el que se conservan noticias más antiguas en este sentido, tal como ya vimos al hablar de los pastos.

E1 23 de marzo de 1382 los jurados de Elche escribieron al infante Martín a propósito de la queja presentada por los judíos de la villa, algunos de los cuales eran dueños de ganados, diciendo que ellos estaban exentos del pago del montazgo. La queja venía del hecho de que cuando los de Orihuela subían el ganado a la sierra estaban exentos del pago, mientras que los de Elche habían de pagar, por lo que reclamaban el mismo trato y la citada exención ${ }^{99}$.

\footnotetext{
96. A.M.E. Manual de Consells, 14. 19-2-1451, Elche.

97. A.R.V. Maestre Racional, 4543, fol. 8 r. Años 1376-1378.

98. Ferrer i Mallol, Ma . T., Pastures i ramadería..., p. 82.

99. A.M.E. Manual de Consells, 1. 25-3-1382, Elche.
} 
La señoría de Elche tenía la plena propiedad sobre los herbajes de la Casa Blanca en los términos de Elche y Crevillent, los «Balsars» y la Devesa del Port, que arrendaba anualmente desde octubre a marzo-abril, destinándose al ganado forastero, trashumante. Fuera de este periodo, los vecinos se aprovechaban de la sosa, la caza y otras hierbas que proporcionaba el territorio. En 1461, siendo señora de la villa la reina doña Juana, este derecho se arrendó por la suma de 60 sueldos ${ }^{100}$.

Las hierbas de la Casa Blanca se arrendaban conjuntamente con las del término de Crevillent y dentro del conjunto de la renta señorial representaban un porcentaje insignificante. En 1399 las arrendó Pere Monistrol, de Elche, por el periodo que iba desde octubre hasta Pascua, por la suma de 52 sueldos, de los que 26 eran de la Casa Blanca. En 1400 el arrendador fue el ilicitano Miquel Sançano, proporcionando unos ingresos de 2 sueldos y 6 dineros. Entre 1411 y 1413 el arriendo se lo quedó Joan Marí, de Alcoi, por un total de 50 sueldos en el año 1411, de los cuales 25 eran por la Casa Blanca, cantidad que descendió a la mitad en 1412 y $1413^{101}$. Si lo comparamos con los más de 2.000 sueldos que proporcionaba el derecho de aduana en Elche, podremos comparar la importancia que la ganadería tenía como fuente de ingresos para la señoría. En 1461 la expansión ganadera se tradujo en un incremento de losingresos, que fueron de 90 sueldos.

Tampoco rentaban mucho más el herbaje del «Fondó o balssars» y la dehesa de la Serra del Port, es decir la actual Serra de Santa Pola. En 1399 lo arrendó Bernat Codines por un año, siempre en el periodo comprendido entre octubre y Pascual, por 200 sueldos, de los cuales el rey se quedó con 40 sueldos por el herbaje de la dehesa, a los que hubo que añadir el pago de otros 160 sueldos a Ramona, la mujer de Joan Blasco, según orden dada por el infante Martín, por la tercera parte que le debían de estas tierras.

En 1400 el arrendador fue Joan Domínguez, por la suma de 30 sueldos, de los cuales 8 fueron a manos del rey por herbaje de la dehesa, quedando netos para la señoría 22 sueldos. En 1411 el ilicitano Antoni Sansalini se quedó con el arriendo por 30 sueldos, de ellos 6 para el rey, y 24 fueron para la señoría, cantidad que subió a 35 sueldos en 1412, cuando Joan Marí, de Alcoy, se quedó con el arriendo. En 1413 el arrendador fue Bernat Vilaplana, por 32 sueldos y 6 dineros, quedando netos para la señoría 23 sueldos y 4 dineros. En 1464-1467 se observa también una tendencia alcista en el arriendo de este herbaje de los Balsars y la Devesa del Port, que lo fue por la suma que osciló entre los 52 y los 76 sueldos

100. Ibarra y Ruiz, P., Historia de Elche, Alicante, 1895. Don Pedro Ibarra afinó tanto, que valoró la recaudación de este impuesto en 10 pestetas y 60 céntimos de las de la época.

101. A.R.V. Maestre racional, 9717, fol. 15 r, y 9718, fol $36 \mathrm{v}$. 
y 6 dineros, mientras que la Casa Blanca lo fue entre 103 y 160 sueldos por la parte de Elche y otro tanto por Crevillent.

Como ya dije al hablar de la trashumancia, ésta generaba unos ingresos en virtud de las licencias concedidas por el señor para pastar, que era de cinco sueldos por centenar de cabezas, en tanto que la villa percibía los ingresos procedentes de los «clams», las degüellas y el derecho del paso, de escaso moto a finales del siglo XV.

También el obispado de Cartagena percibía el diezmo de la lana de los ganados, y para no perder ingresos por la trashumancia estival, en 1389 el obispo dispuso que los ganados que fueran sacados de su obispado del mes de marzo en adelante pagaran el diezmo de la lana en el lugar de donde fuera vecino el propietario, aunque ya hubiera pagado el diezmo en el lugar donde pastoreó el ganado o fue esquilado. El diezmo se percibía también sobre el ganado vacuno, a razón de 15 dineros por ternero, aunque los arrendadores del diezmo en 1378 pretendieron que fuera de un ternero por cada diez. Esto motivó la indignación del infante Martín, señor de Elche, ya que lo consideró una intromisión en su jurisdicción ${ }^{102}$.

Señalemos que el Consell recibió una notificación el 5 de mayo de 1465 de los mensajeros de la villa diciendo que habían obrtenido una provisión de la reina, como lugarteniente general del rey, por la que se autorizaba al Consell ilicitano a percibir de todos los ganados que pasaran por el Pas Nou un sueldo al año por centenar de cabezas ${ }^{103}$

\section{EL MERCADO Y LAS UTILIDADES GANADERAS}

En todas las poblaciones valencianas se desarrolló durante los siglos bajomedievales un activo mercado ganadero, con un radio de acción mayor o menor, según la importancia que la ganadería tuviera en la economía local. Es obvio que Elche no era Morella o San Mateo, pero también aquí la compra-venta de animales fue habitual, y como tal aparece reflejada en los protocolos notariales que se conservan, a partir del último cuarto del siglo Xv. Así, entre 1473 y 1505 se realizaron operaciones mercantiles con 5.100 cabezas de ganado, de las cuales unas 900 eran cabras, 1.043 ovejas y 3.053 carneros, testimonio de las preferencias a la hora del consumo de carne entre los ilicitanos, que en nada se diferenciaban de sus compatriotas de otras localidades regnícolas.

La compra de animales se realizó también a vecinos de otras poblaciones, como Cocentaina, Bocairente o Castilla, localidades cuyos ganados invernaban

102. Ferrer i Mallol, Ma . T., Pastures i ramadería..., p. 93.

103. A.M.E. Manual de Consells, 16, 5-5-1465, Elche. 
en Elche, Rojales o Callosa de Segura, en tanto que los ilicitanos también vendían sus ganados a los forasteros, como las 146 cabras vendidas el 13 de febrero de 1481 por Çaat Bormocia, alias «Puruig», moro de Elche, a Jaume Díez, de Guardamar; o las 307 ovejas, un asno y un perro que Berenguer d'Alvado, vendió a Guillem Pérez y Andreu Guillem de Jijona en noviembre de $1486^{104}$.

Las transacciones eran parte de las actividades mercantiles cotidianas y son difíciles de percibir en su realidad total si carecemos de los protocolos notariales, y sólo cuando surgen conflictos e intervienen las autoridades municipales podemos seguirles la pista. Es lo que sucedió el 19 de diciembre de 1451, cuando Berenguer d'Oco y Antoni Calom, vecinos de Elche, explicaron al Consell que ellos hacía cinco años compraron, junto con el notario Pere Bataller, cierto ganado en Bocairent a Bertomeu Boda. Se les exigió que pagaran el peaje, a lo que respondieron mostrando las franquicias de la villa, por lo que pudieron pasar sin más problemas. Pero hacía unos días el Justicia de Bocairent les habían exigido el pago de 33 sueldos por vía de apremio, sin que la franquicia les sirviera de excusa, pues ahora la franquicia de Xàtiva no servía en Elche. El Consell acordó escribir al de Bocairente y reclamar la devolución de los citados 33 sueldos.

Vemos como los más activos y los que mejores operaciones de compra-venta de ganado son miembros de la «burguesía» local, como los citados Antoni Calom, el tantas veces citado Pere Bataller, o Berenguer d'Alvado, que también fue mensajero del Consell, por lo que -además de capital-disponían de amplias relaciones en todo el reino; o el mercader Ferrando de Madrit, asegurador de la carne durante varios años en esta década de los ochenta, que el 29 de abril de 1487 vendió por mediación del carnicero valenciano Joan Çabater 302 carneros, al precio de 11 sueldos la cabeza, a una sociedad mercantil integrada por nobles, ciudadanos y operadores mercantiles genoveses, todos ellos residentes en Valencia. Eran éstos el noble Gaspar Rull, los ciudadanos y mercaderes Galcerà Adret y Lluís Pellicer, además de los mercaderes genoveses Bernardo de Franquis, Giovanni Socius, Honorato Cipriani y Rafael Gentil, que habían sido arrendadores de la sisa de la carne en 1486. El pago se haría en Valencia en el momento en que Madrit quisiera, y de no hacerse, el vendedor podría tomar los carneros y venderlos de nuevo, percibiendo 10 sueldos por día de viaje y la estancia, además de los gastos ${ }^{105}$. Al día siguiente otro mercader ilicitano, García de Almansa, les vendió a la misma sociedad 590 carneros, a 10 sueldos y 3 dineros la cabeza, con las mismas condiciones de pago citadas. Todos los compradores son nombres conocidos para quienes bucean en las fuentes documentales valencianas

104. A.M.E. Protocolos notariales, no 9, fol. 176 v y 10, fol. 114 v. 4-11-1486, Elche.

105. A.M.E. Protocolos notariales, $\mathrm{n}^{\circ}$ 10, fol. 178 r. Puede verse que el precio de los carneros había subido ligeramente -3 dineros- con relación a las ventas del año 1486. 
bajomedievales, ya que formaban parte de la oligarquía mercantil de la ciudad, dedicados al comercio pero también a la especulación con el abastecimiento de carne a la ciudad.

Madrit compró también ganado en Castilla para abastecer el mercado cárnico ilicitano, y el 13 de enero de 1487 nombró procuradores a Pere Bernabeu y a Domingo de Soria para comprar ganado cabrío y lanar en Castilla. En diciembre de este año hizo otra procura a favor de su hijo Joan de Madrit y el pastor Domingo de Soria, criado de Ferrando, para comprar más ganado.

En estos años ochenta -no sabemos qué pasó antes, por falta de documentación notarial- Valencia tenía en Elche una más de sus fuentes de abastecimiento cárnico, y los mercaderes de ambas poblaciones estaban en contacto para realizar operaciones conjuntas. A las arriba citadas hay que añadir otras, en las que, una vez más, vemos actuar como intermediaros y agente efectivo de la operación a un carnicero de Valencia. Se trata de la obligación hecha ante el notario del 23 de mayo de 1486 por Jaume Martí, alias «Gumela», carnicero de Valencia, en su nombre y como procurador del noble Francesc Vives de Boïl, señor de Bétera, Xirivella, Massamagrell y Massanasa, en l'Horta de Valencia, y de los mercaderes Lluís Pellicer, Francesc boscá y Galcerà Adret, de abonar 147 libras y 14 sueldos por la compra a Juan de Luján, procurador de Gutierre de Cárdenas, de 307 carneros, a 9 sueldos y 9 dineros. Ese día el mismo carnicero compró al ya citado García d'Almansa otras 180 cabezas. Operaciones mercantiles, por tanto, realizadas en un pequeño círculo de vendedores, Alvado, Madrit, Almansa, Luján, y de compradores ilicitanos. La mayoría de los otros compradores y vendedores son gentes del reino de Valencia: de Orihuela, Guardamar, Catral, Monforte, Jijona, Alicante, Callosa, Novelda, Almoradí, Albatera, es decir, de la gobernación de Orihuela y localidades limítrofes por el norte. Los de fuera del reino son pocos y proceden de Murcia y, sobre todo de Yecla, siendo la mayoría carreteros, como Juan Quilis (1499), Pedro Ortunyo (1487), algún recuero de Chinchilla, como Alfonso Roiz (1487)

En cuanto al ganado mayor, mulos, asnos, rocines, etc., el que se utilizaba para la labranza, el transporte o la representación social, todo el amplio espectro social de Elche participó en la compra y venta de estos animales, desde labradores y pelaires a clérigos. Sin embargo, una vez más, volvemos a encontrarnos a los hermanos Alvado (Alfons, Bertomeu, Joan y Guillem) como los principales vendedores en estas décadas finales del siglo XV y comienzos del XVI, con un total de veintiuna operaciones.

También el ganado era utilizado como moneda de cambio para la permuta de bienes, desde tierra a otros animales. Así, vemos el 19 de agosto de 1484 a mosén Joan d'Ancano, cambiar un macho con su albarda y dos cahíces y medio 
de cebada por cinco tahullas de viña y cuatro de tierra blanca con higueras y granados, que le dio Miquel Martínez.

En ocasiones, sobre todo cuando hubo problemas de abastecimiento de carne, fue el Consell el que se encargó de regular las transacciones comerciales con el ganado local, impidiendo su salida de la villa. De ahí la orden dada por los jurados el 16 de septiembre de 1408 a Na Guillamona, viuda de Jaume Rubio, para que trajera a la villa o su término el ganado que había vendido a los mudéjares de Crevillent, dado que no podía realizar dicha venta como consecuencia de las prohibiciones dictadas por el Consell en torno a los ganados locales. De no hacerlo, Pau Yanyes, notario, síndico y procurador del Consell, procedería contra la mujer, por haber vendido el ganado sin permiso y contra las ordenanzas vigente ${ }^{106}$.

Otras veces optó por la táctica de concentrar todos los animales de los vecinos en rebaños y destinarlos a la canicería local. Es lo que hizo el 5 de marzo de 1452 , al no encontrar asegurador de la carne, disponiendo que todos los cristianos y musulmanes de la villa llevaran todos su animales machos de lanar a pastar a la huerta. Que los dueños de los ganados entre todos haban «rabera» de 220 cabezas de ganado cada una, abonando a prorrateo los gastos de los pastores que sean necesarios para llevar este ganado y su vigilancia. Pastará por los lugares permitidos a los aseguradores del año anterior y se requiere al procurador general a que libere los ganados embargados y permita que vayan a pacer a la huerta ${ }^{107}$.

La liberalización de la venta de ganado macho se produjo por una disposición concejil del 20 de abril de 1409, que autorizaba la venta de este ganado por parte de los vecinos a cualquier persona, percibiendo los jurados la fadiga antes de su venta, si se lo querían comprar a algunos vecinos. Y el 16 de mayo el Consell comisionó a Pau Yanyes, notario y síndico municipal, para que requiriera al procurador de la villa a dar licencia a los vecinos para poder vender su ganado sin pena alguna, dando fadiga primero a los vecinos si quisieran comprar por el precio que el forastero diera. Se mantenía la prohibición de sacar ganado de la villa y su término, bajo la pena de 100 morabatines.

De nuevo el 17 de enero de 1415 los jurados prohibieron que el ganado lanar macho (corderos, borregos y cabrones) de los vecinos saliera de la villa sin permiso del Consell hasta que éste dispusiera lo contrario, a fin de tener bien abastecido de carne el mercado. El que quisiera sacar ganado debía contar con permiso del Justicia y de los jurados.

Otras veces, el Consell daba licencia a particulares para vender ganado propio con el fin de satisfacer embargos, procesos, etc, como hizo el 19 de noviem-

106. A.M.E. Manual de Consells, 2. 16-9-1408, Elche.

107. A.M.E. Manual de Consells, 14. 5-3-1452, Elche. 
bre de 1423 con Beneito Bataller, vecino de la villa, al que se autorizó a vender cien machos entre corderos y cabrones, así como la lana que sacara del citado ganado, debiendo presentar el precio de la venta ante el procurador general, en razón de la ejecución que éste llevaba en el proceso contra Pere de Lorca y su mujer, Jaume Sánchez de Lorca y el citado Bataller ${ }^{108}$.

En cuanto a las utilidades, uno de los interrogantes que tenemos por resolver es el de saber que se hace con esta ganadería, con su carne, pieles, lana, etc, y quiénes eran sus beneficiarios. Del aprovechamiento lácteo y quesero del ganado lanar y cabrio carecemos de informaciones, dado que las fuentes que manejamos son de carácter público y en ellas no se encuentran alusiones a tales productos, que estaban restringidos al marco del consumo doméstico. Sin duda, la carne y la producción de materias primas para la artesanía local constituían el principal aprovechamiento derivado de la ganadería.

Sabemos que pelaires y zapateros compraban las pieles a los carniceros y al asegurador de la carne de la villa, que las vendían por anticipado, como era habitual. El 31 de enero de 1480, por ejemplo, el pelaire Francesc Lluna, se comprometió a comprar y pagar al carnicero Pere Alfonso todas las pieles de los cabritos que matara desde esa fecha hasta San Juan, a cinco sueldos la docena ${ }^{109}$. El mismo pelaire se quedó el 22 de febrero de 1481 a comprar a Esteban Pacheco y Baltasar Vives, mercaderes, todo el cuero del ganado lanar de los cristianos, de las carnicerías de la villa, a 20 sueldos la docena. Ambos mercaderes suministraron también cuero en 1487 a Alfonso de Villarreal, zapatero, mientras que el 15 de octubre de 1498 el pañero Ferrando de Andújar se comprometió a pagar 60 sueldos que debía al zapatero Antoni Palma por cuero. Vemos, por tanto, un mercado ganadero y de sus derivados, controlado por un reducido grupo de mercaderes de la elite local, que son los que controlan la compra-venta de ganado y de sus derivados, las pieles, la lana y abastecían de carne al mercado local.

De los cueros encontramos también información en los capítulos de la sisa, $\mathrm{y}$ en 1461 se dice textualmente:

«Item, qualsevol persones stranyes o privades que de la dita vila de Elig e terme de aquella trauran cuyram lanar e cabriu, paga per dret de sisa per cascuna dotzena de cuyram sis diners. E axi mateix pague per dret de sisa sis diners per cascun cuyro de bou ho de vaca, ho de qualsevol altra res bovina que trauran de la dita vila e terme de aquella, declarants emperò que ls çabaters de la dita vila puxen traure dels dits cuyros e cuyrams de la dita vila sens pagar sisa per

108. A.M.E. Manual de Consells, 5. 19-11-1423, Elche.

109. A.M.E. Manual de Consells, Protocolos notariales, $n^{\circ}$ 5, fol. 7 r. 
adobar..., emperò que manifesten als dits sisers los dits cuyrams, axí de treta com de entrada, sots pena de sexanta sous o pagar lo dret en doble» ${ }^{110}$.

La sisa se estableció, por tanto, en seis dineros por docena de cueros de ganado lanar y cabrio, o por cada piel de toro o de vaca, o de otra res bovina. Con objeto de favorecer la industria del cuero, en concreto del calzado, que ya comenzaba a despuntar en Elche, las autoridades municipales declaraban exentos los cueros de los zapateros que se sacaran para adobar, con la condición de declararlos al sisero, ya que de contrario serían multados con 60 sueldos.

No hay muchas más informaciones sobre la venta y comercialización de la lana local, que a tenor del volumen ganadero tampoco cabe suponer fueran muy altas. Así, por ejemplo, el 21 de enero de 1486 Ginesa y su hijo el presbítero mossén Salamó, vendieron 17 arrobas de lana blanca y negra, a 12 sueldos la arroba, a Caterina, viuda del molinero Joan Serra. También el 7 de mayo de 1486 el ya tantas veces citado Ferrando de Madrit, asegurador de la carne, vendió 93 arrobas de lana. Igualmente los miembros de la familia Alvado, Alfonso y Berenguer (1497), Joan (1506) participaron en la venta de lana, cuyo destino final ignoramos, aunque quizá fuera a la industria pañera local, y con seguridad a la de Orihuela, Cocentaina y Alcoy, en plena eclosión a fines de la Edad Media. Así se desprende de la venta el 7 de mayo de 1486 por Ferrando de Madrit de 93 arrobas de lana blanca y negra, a 15 sueldos y 9 dineros la arroba, a los pelaires de Orihuela Bertomeu y Francesc Almodòver. También Madrid vendió cien arrobas de lana, a 16 sueldos, al pelaire oriolano Pere Fernández, que el 17 de abril de 1487 se comprometía a pagarle 1.100 sueldos de los 1.600 que costó dicha lana ${ }^{111}$. La lana con destino a Cocentaina la vendieron Alfons y Berenguer Alvado el 2 de diciembre de 1497, por un total de 27 arrobas, y 60 arrobas fueron vendidas por Joan Alvado en julio de 1506 a los pelaires alcoyanos Ginés Macià y Siprés Abat.

Las autoridades locales trataron siempre que, igual que sucedía con la carne, la villa estuviera bien provista de lana para atender las necesidades de sus vecinos, tanto en las labores domésticas como en la industria local. Estas medidas proteccionistas no sabemos de cuándo datan, pero son antiguas y se documentan en los capítulos de la sisa local, donde se dice que el vecino que tuviera ganado no debía llevarlo a esquilar a otra localidad, con el fin de que no se perdiera el derecho de la sisa, y estaba obligado al esquileo en Elche. Si para mejorar su ganado o por razones económicas quisiera hacerlo en otro lugar, en este caso se le autoriza pero pagando en Elche, de donde era vecino, la sisa.

110. A.M.E. Manual de Consells, 16, fol. 31 r-v. 9-4-1461, Elche.

111. A.M.E. Protocolos notariales, $\mathrm{n}^{\circ} 10$, fol. 59 r y $173 \mathrm{v}$. 
En la sisa del año 1380 se establecía que todo aquel que comprara lana en Elche y su término abonara un sueldo por arroba. En 1461 la sisa establecía el pago de seis dineros por cada arroba para aquellos que sacaran lana de Elche y de su término, salvo los que sacaren la lana para teñirla y luego la reintegraran a la villa.

Si en un caso predominaron razones fiscales, en otros fueron razones de aprovisionamiento para la industria textil local. En otro acuerdo municipal del 21 de febrero de 1409, el Consell dispuso que los dueños de los ganados no los llevaran a esquilar fuera de la villa, a fin de que la lana se destinara a los vecinos. Si los vecinos quisieran comprar lana al precio ofrecido por el mercader, local o forastero, que pudiera comprar la lana necesaria para vestir o para su obrador, hasta dos piezas. Los jurados prohibieron a los vecinos vender lana a vecinos o forasteros si ésta se destinaba a la exportación, debiendo ofrecer la oportunidad de comprarla a todo vecino que quisiera, al mismo precio que el dado al mercader, bajo la pena de 60 sueldos, todo ello con el objetivo de que la industria local no quedara desabastecida de materia prima ${ }^{112}$. Conviene recordar que en Elche la manufactura de paños fue la industria local más importante a fines de la Edad Media, como ya destaqué en otro trabajo. Se trataba de obradores de tipo familiar, que producían tejidos de media o baja calidad, destinados al mercado local, o a lo sumo comarcal, y no hay noticias de su exportación. Las fuentes documentales aluden a tejedores, pelaires y tundidores, aunque no tintoreros, lo que indica que Elche concentraba su industria textil en las operaciones finales del proceso de transformación de la lana. Los pañeros, que controlaban también el proceso de fabricación del paño, reduciendo al menestral a un simple asalariado, se encargaban también de la comercialización del producto acabado ${ }^{113}$

En 1461 las autoridades, en los capítulos de la sisa seguían insistiendo en la prohibición de esquilar el ganado fuera de Elche y su término «per tal que 'l dret de sisa no's perda», pagando el «dret de treta» el que lo hiciera fuera ${ }^{114}$.

\section{LA GANADERÍA DE LOS MUDÉJARES}

Aunque los mudéjares ilicitanos se dedicaron básicamente a la agricultura y a la artesanía, como en todas partes el ganado constituía un complemento a tales dedicaciones y siempre tuvo un marcado carácter familiar. Tras la conquista cris-

112. A.M.E. Manual de Consells, 2. 21-2-409, Elche.

113. Hinojosa Montalvo, J., «La industria en Elche en la Baja Edad Media» en IX Jornades d'Estudis d'Història Local. La manufactura urbana i els menestrals (s. XIII-XVI). Palma de Mallorca, 1991. pp. 83-96.

114. Hinojosa Montalvo, J., Barrio Barrio, J.A., «Las sisas en la gobernación de Orihuela durante la Baja Edad Media», en Anuario de Estudios Medievales, 22, 1992, pp. 535-579. 
tiana, los ahora mudéjares continuaron en posesión de sus ganados, de acuerdo con los pactos de capitulación. Pero las guerras que azotaron la comarca siempre tuvieron en los mudéjares una de sus primeras víctimas, en particular sus propiedades, como fue el caso del ganado. Con ocasión de la conquista del reino de Murcia por Jaime II sabemos que estos mudéjares ilicitanos, entre otros, fueron objeto de algunas violencias, y el 15 de junio de 1296 Jaime II ordenó a los bailes de Orihuela y Guardamar que recogieran a los moros de Elche, Crevillent y el valle de Elda que, según sus noticias, estaban retenidos con su ganado por algunos vecinos de estas villas, entregándolos al portero que llevaba la misiva, dado que estaban bajo su especial salvoconducto ${ }^{115}$.

El impuesto del atzaque es la principal fuente para conocer el número de cabezas que componían la cabaña mudéjar. Del siglo XIV ha quedado noticias concretas del mencionado impuesto para el año 1315, en que rendía la suma de 500 sueldos, y teniendo en cuenta que cada cabeza de ganado abonaba dos dineros, resulta una cifra de 3.000 cabezas de ganado menor. En la segunda mitad de la centuria, tras la guerra de los «dos Pedros», que ocasionó la pérdida de buena parte de dicho ganado, por los datos conservados para Elda y Novelda vemos que se produjo un auténtico desastre ganadero en las comarcas de la gobernación de Orihuela, del que también resultaría afectada Elche, sin que podamos precisar más, ni tampoco cuándo se produjo la recuperación de la cabaña, pero todo apunta a una rápida vuelta a la normalidad, al menos esto es lo que sucedió en la vecina Aspe ${ }^{116}$.

En el siglo Xv, recuperado el ritmo cotidiano de la vida económica de la aljama, ésta tenía 207 cabezas de ganado lanar y caprino, que en 1400 descendieron a 76 cabezas, sin que sepamos la razón. Para el año 1411 el aumento de la cabaña había sido espectacular y ya tenía 1.813 cabezas, que descendieron a 1.450 en 1412 y a 1.143 en 1413, pero ignoramos todo lo referente a la evolución de este ganado, desde su distribución por especies al número de cabezas por cada casa, epidemias, etc. Tan sólo la autorización concedida por el Consell el 22 de abril de 1436 a Llorens Bonmatí, Amet Sarrió y al alfaquí para que pudieran vender 180 ovejas y corderos al precio que mejor encontraran, lo que sugiere una posible participación conjunta de cristianos y mudéjares en la constitución de rebaños ${ }^{117}$.

115. A.C.A. C. reg. 340, fol. 144 r. 15-6-1296, Elche.

116. Ferrer i Mallol, M $\mathrm{M}^{\mathrm{a}} \mathrm{T}$., Les aljames sarraïnes de la Governació d' Oriola en el segle XIV, Barcelona, C.S.I.C.-Institució Milà i Fontanals, Barcelona, 1988, pp. 118-120.

117. Hinojosa Montalvo, J., La morería de Elche en la Edad Media, Teruel, Instituto de Estudios Mudéjares, 1994. 
El ganado pacía en el bovalar de la villa, junto con el de los cristianos, y los mudéjares contribuían con un tercio de los gastos que ocasionaba su mantenimiento. La aljama, en cambio, no recibía nada en concepto de las multas abonadas por la invasión de su huerta.

Este ganado fue también una fuente de ingresos para la señoría, y ya desde la conquista cristiana aparecen regulados los impuestos sobre el ganado, cuyo precedente islámico es zaqat sobre los objetos en crecimiento. La posesión por el señor del dominio directo de las tierras le autorizaba a exigir un censo por el uso y aprovechamiento de las mismas para el pasto de los ganados. La exacción más importante era el del zaque (atzaque en otras localidades). Aparece definido como el que «los moros dels dits orta e raval pagaren a la dita ciutat, qui es dret que tot moro que aja bestiar lanar ho cabriu que sia sobre any» paga cada año 2 dineros por cabeza. El alcadí y los viejos de la aljama se encargaban de certificar la veracidad de los datos, inspeccionando el ganado cabrío y lanar que había en cada casa. Entre 1399 y 1413 arrojó los siguientes resultados:

\begin{tabular}{|l|l|l|l|l|l|}
\cline { 2 - 6 } \multicolumn{1}{c|}{} & \multicolumn{1}{c|}{$\mathbf{1 3 9 9}$} & \multicolumn{1}{c|}{$\mathbf{1 4 0 0}$} & \multicolumn{1}{c|}{$\mathbf{1 4 1 1}$} & \multicolumn{1}{c|}{$\mathbf{1 4 1 2}$} & \multicolumn{1}{c|}{$\mathbf{1 4 1 3}$} \\
\hline cabezas & 207 & 76 & 1.813 & 1.450 & 1.143 \\
\hline impuesto & 36 s. 6 d. & 12 s. 8 d. & 302 s. 2 d. & 241 s. 8 d. & 190 s. 6 d. \\
\hline
\end{tabular}

Otro impuesto que recaía sobre el ganado era el llamado dret de asveig, abonado por todo moro que tuviera animal para labrar. Consistía en la entrega por cada par de bestias de una barchilla de cebada y de dos almudes si era sólo un animal. En el caso de tener más sólo se contaba un par. En 1399 fueron 128 los animales de labrar, lo que supuso una recaudación de 5 cahíces y 4 barchillas de cebada. Después quedaron reducidos a 5 cahíces como consecuencia de las pérdidas y disminuciones, que se estimaban, según la costumbre, en 3 almudes por cahíz. Vendidos a 16 sueldos el cahíz arrojaron unos beneficios netos para la señoría de 80 sueldos.

En 1400 las bestias de labrar que tenían los mudéjares eran 115, recaudándose un total de 4 cahíces y 6 barchillas netas de cebada, vendidos a 15 sueldos, 6 dineros, lo que da un beneficio de 70 sueldos, 6 dineros, En 1411 fueron 131 animales de labrar, con un total de 5 cahíces, 1 barchilla y 2 almudes de cebada, vendidos a 15 sueldos, 6 dineros, totalizando el ingreso para la señoría 79 sueldos, 5 dineros. En 1412 disminuyeron los animales hasta 123, con un total de 4 cahíces, 9 barchillas y 3 almudes de cebada. Fue vendida a 20 sueldos el cahíz, con unos beneficios de 96 sueldos y 3 dineros. Por último, en 1413, los animales de labrar, eran 125 y la cebada 4 cahíces y 10 barchillas. Pero el aumento del precio de la cebada, que pasa a 22 sueldos, 7 dineros el cahíz, permitió aumentar dicha renta hasta 110 sueldos, 2 dineros. Por tanto, tendencia a la estabilidad de este impuesto, con tendencia al alza en función del precio de la cebada. 
Por último señalemos la existencia de un activo mercado ganadero a cargo de la comunidad mudéjar local, del que tenemos noticias por las multas impuestas por las autoridades al intentar defraudar el pago de los correspondientes impuestos, en este caso el derecho de la aduana. En el año 1461, el baile de la villa, Pau Rossell, multo a los siguientes mudéjares: Abçey Hendal, Amet Sarriá, Acili Beagip, Alí Aparici, Ciçelim Calema, Aycaf Roget, Edad Porrug, la muller Zaem, mora, Azez, alcadí, Abadía Bauquexa y Zaat Uzenta, todos ellos multados con algunos sueldos por la venta de ovejas, macabras y cabrones, percibiendo la reina Leonor, señora de Elche, la mitad del importe de dicha penalización. 